\title{
Selected Hydrologic Data from Fortymile Wash in the Yucca Mountain Area, Nevada, Water Years 1993-94
}

By Charles S. Savard

$$
\text { USGS-OFR- } 95-709
$$

U.S. GEOLOGICAL SURVEY

Open-File Report 95-709

Prepared in cooperation with the NEVADA OPERATIONS OFFICE

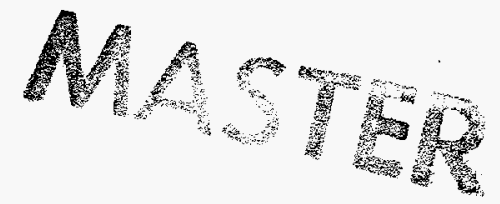

U.S. DEPARTMENT OF ENERGY under

Interagency Agreement DE-Al08-92NV10874

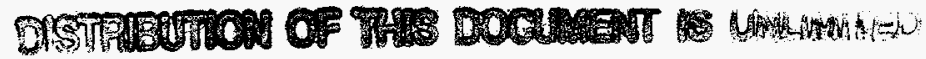

Denver, Colorado

1996

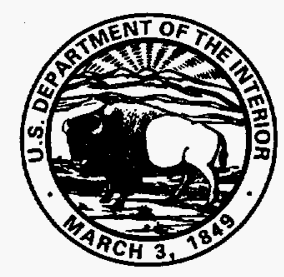




\section{U.S. DEPARTMENT OF THE INTERIOR \\ BRUCE BABBITT, Secretary \\ U.S. GEOLOGICAL SURVEY \\ Gordon P. Eaton, Director}

\section{DISCLAIMER}

This report was prepared as an account of work sponsored by an agency of the United States Government. Neither the United States Government nor any agency thereof, nor any of their employees, makes any warranty, express or implied, or assumes any legal liability or responsibility for the accuracy, completeness, or usefulness of any information, apparatus, product, or process disclosed, or represents that its use would not infringe privately owned rights. Reference herein to any specific commercial product, process, or service by trade name, trademark, manufacturer, or otherwise does not necessarily constitute or imply its endorsement, recommendation, or favoring by the United States Government or any agency thereof. The views and opinions of authors expressed herein do not necessarily state or reflect those of the United States Government or any agency thereof.

The use of trade, product, industry, or firm names is for descriptive purposes only and does not imply endorsement by the U.S. Government.

For additional information write to: Chief, Earth Science Investigations

Program

Yucca Mountain Project Branch

U.S. Geological Survey

Box 25046, MS 421

Denver Federal Center

Denver, CO 80225
Copies of this report can be purchased from: U.S. Geological Survey Information Services Open-File Reports Section Box 25286, MS 517 Denver Federal Center Denver, CO 80225 
DISCLAIMER

Portions of this document may be illegible in electronic image products. Images are produced from the best available original document. 


\section{CONTENTS}

Abstract

Introduction

Purpose and scope

Previous work

Quality assurance

Acknowledgments

Hydrologic data

Precipitation data

Streamflow data

Unsaturated-zone water-content profiles

Depth-to-water data

Summary

Water-quality data

References cited

\section{FIGURES}

1. Map showing location of gaging stations, crest-stage gages, neutron-access boreholes, and wells in the Yucca Mountain area, Nevada

2. Graphs showing cumulative precipitation at UE-29 UZN\#91 and UE-29 UZN\#92 sites in the Yucca Mountain area, Nevada, during water year 1993

3. Graphs showing cumulative precipitation at UE-29 UZN\#91 and UE-29 UZN\#92 sites in the Yucca Mountain area, Nevada, during water year 1994

4. Photograph showing Delirium Canyon tributary velocity section in the Yucca Mountain area, Nevada, on March 31, 1992.

5. Photograph showing Delirium Canyon tributary velocity section in the Yucca Mountain area, Nevada, on January 19, 1993

6. Graphs showing volumetric water-content profiles for UE-29 UZN\#91 in the Yucca Mountain area, Nevada

7. Graphs showing volumetric water-content profiles for UE-29 UZN\#92 in the Yucca Mountain area, Nevada

8-10. Hydrographs showing depth-to-water measurements in:

8. UE-29 a\#1 in the Yucca Mountain area, Nevada.

9. UE-29 a\#2 in the Yucca Mountain area, Nevada.

10. UE-29 UZN\#91 in the Yucca Mountain area, Nevada

\section{TABLES}

1. Precipitation totals for the UE-29 UZN\#91 site, Yucca Mountain area, Nevada, during water year 1993

2. Precipitation totals for the UE-29 UZN\#91 site, Yucca Mountain area, Nevada, during water year 1994

3. Precipitation totals for the UE-29 UZN\#92 site, Yucca Mountain area, Nevada, during water year 1993

4. Precipitation totals for the UE-29 UZN\#92 site, Yucca Mountain area, Nevada, during water year 1994

5. Gaging station and crest-stage locations in the Yucca Mountain area, Nevada

6. Well and neutron-access borehole locations in the Yucca Mountain area, Nevada

7. Depth-to-water measurements in UE-29 a\#1 in the Yucca Mountain area, Nevada

8. Depth-to-water measurements in UE-29 a\#2 in the Yucca Mountain area, Nevada

9. Depth-to-water measurements in UE-29 UZN\#91 in the Yucca Mountain area, Nevada

10. Chemical composition of water samples obtained in the Fortymile Wash drainage basin in the Yucca Mountain area, Nevada 


\begin{tabular}{rll}
\hline Multiply & By & To obtain \\
\hline centimeter (cm) & & inch \\
foot (ft) & 0.3937 & meter \\
inch (in.) & 0.3048 & centimeter \\
inch (in.) & 2.54 & millimeter \\
kilometer (km) & 25.40 & mile \\
meter (m) & 0.6214 & foot \\
mile (mi) & 3.281 & inch \\
\hline
\end{tabular}

Degree Celsius $\left({ }^{\circ} \mathrm{C}\right)$ may be converted to degree Fahrenheit $\left({ }^{\circ} \mathrm{F}\right)$ by using the following equation:

$$
{ }^{\circ} \mathrm{F}=9 / 5\left({ }^{\circ} \mathrm{C}\right)+32 .
$$

Sea level: In this report "sea level" refers to the National Geodetic Vertical Datum of 1929 (NGVD of 1929)-a geodetic datum derived from a general adjustment of the first-order level nets of both the United States and Canada, formerly called Sea Level Datum of 1929. 


\title{
Selected Hydrologic Data from Fortymile Wash in the Yucca Mountain Area, Nevada, Water Years 1993-94
}

\author{
ByCharles S. Savard
}

Abstract

Precipitation totals of 296 and

277 millimeters were measured at neutron-access boreholes UE-29 UZN\#91 and UE-29 UZN\#92, respectively, during water year 1993, October 1 , 1992, to September 30, 1993. Precipitation totals of 104 and 108 millimeters were measured at UE-29 UZN\#91 and UE-29 UZN\#92, respectively, during water year 1994 , October 1,1993 , to September 30,1994 . Approximately 90 percent of water year 1993 precipitation fell during the period November 16 to March 29. Localized streamflow was generated in the Fortymile Wash drainage basin during precipitation events in January and February 1993 and infiltrated into the streambed materials as it went down the channel system. Enough streamflow infiltrated in the Pah Canyon-Fortymile Wash area to recharge the ground-water system, as evidenced by rises in water levels of more than 3 meters in well UE-29 a\#1, more than 2 meters in UE-29 a\#2, and almost 2 meters in neutron-access borehole UE-29 UZN\#91. Ground-water levels steadily declined after the recharge until October 1994. The streamflow went over the UE-29 UZN\#91 and UE-29 UZN\#92 neutronaccess borehole locations. Neutron logging showed increases in the volumetric water content at UE-29 UZN\#91 to the water table, more than 15 meters deep. Increases at UE-29 UZN\#92 were indicated at depths of up to 8 meters. The volumetric water content then gradually decreased in both boreholes until October 1994. Water samples from streamflow in Pah Canyon Wash and Delirium Canyon Wash and from well UE-29 a\#1 were analyzed for chemical constituents and physical properties.

\section{INTRODUCTION}

The Yucca Mountain area is being evaluated by the U.S. Department of Energy for its suitability to store high-level nuclear waste in a mined, underground repository (U.S. Department of Energy, 1988). Hydrologic data are being collected by the U.S. Geological Survey throughout a $150-\mathrm{km}^{2}$ study area about $150 \mathrm{~km}$ northwest of Las Vegas in southern Nevada (fig. 1) for site characterization studies. Ongoing hydrologic studies are investigating atmospheric precipitation, streamflow, movement of water through the unsaturated zone, movement of water through the saturated zone, and paleohydrology.

This study at Fortymile Wash involves some components of each of these studies. Fortymile Wash is an ephemeral stream near Yucca Mountain with tributaries draining the east side of Yucca Mountain and then forming a distributary system in the Amargosa Desert. An objective of the study is to determine the amount of recharge from Fortymile Wash to the ground-water flow system that has been proposed by Czarnecki and Waddell (1984), Claassen (1985), White and Chuma (1987), and Benson and Klieforth (1989). Understanding the ground-water flow system is important because it is a possible mechanism for radionuclide migration from the potential repository to the accessible environment. An adequate understanding of the ground-water flow system is necessary for an evaluation of the safety issues involved in siting the potential repository.

\section{Purpose and Scope}

The purpose of this report is to compile selected hydrologic data for water years 1993 and 1994, which corresponds to the period of October 1,1992, to September 30, 1994. Precipitation readings and watercontent profiles from two sites (UE-29 UZN\#91 and UE-29 UZN\#92), miscellaneous streamflow observations, depth-to-ground-water data from three sites 


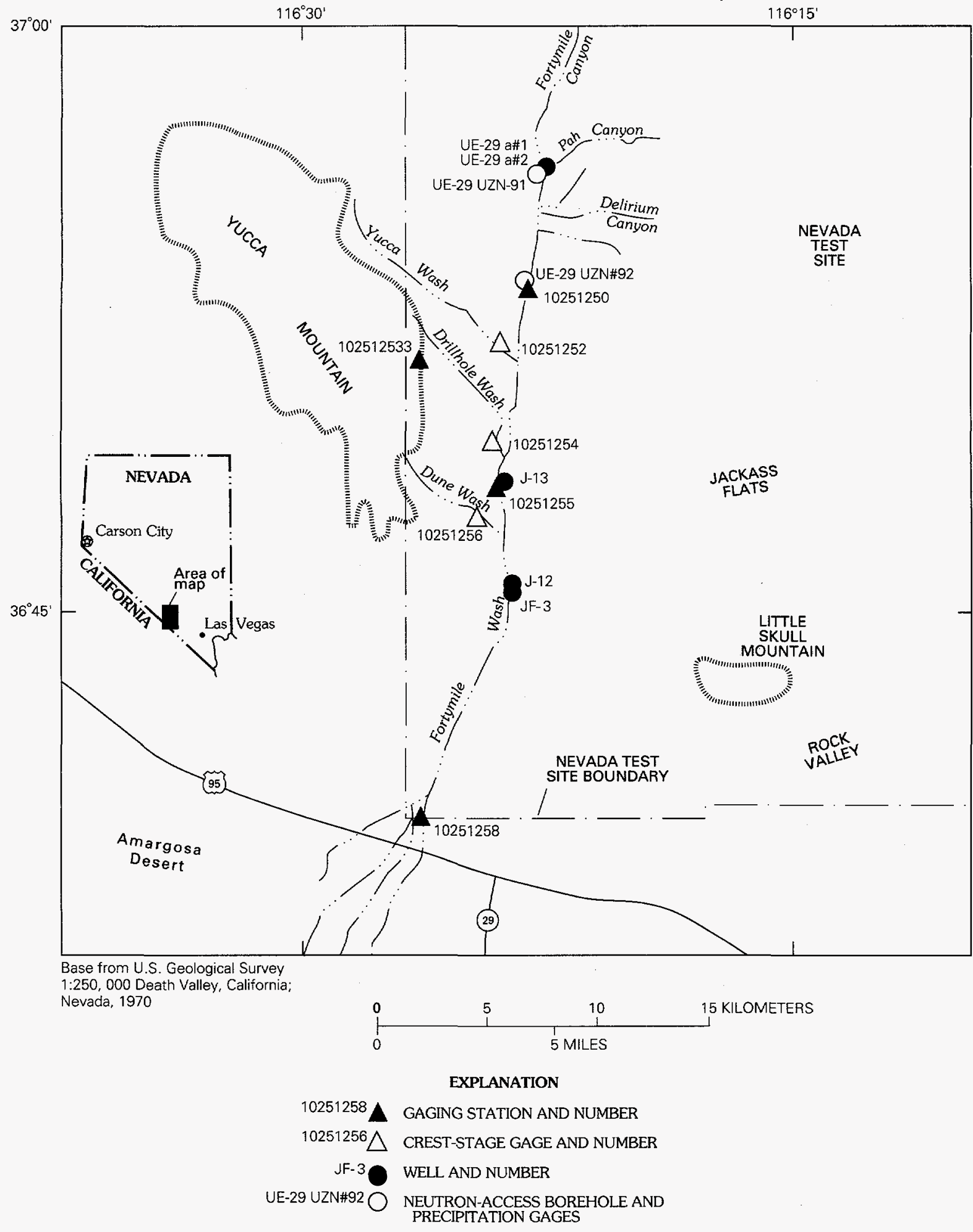

Figure 1. Location of gaging stations, crest-stage gages, neutron-access boreholes, and wells in the Yucca Mountain area, Nevada. 
(UE-29 a\#1, UE-29 a\#2, and UE-29 UZN\#91), and the chemical composition of water from one well site (UE-29 a\#1) and two streamflow sites (Delirium Canyon tributary and Pah Canyon tributary) are presented in this report. These data are considered important to understanding recharge processes to the groundwater flow system in the Fortymile Wash area.

\section{Previous Work}

The U.S. Geological Survey has been investigating the hydrology of the Yucca Mountain area since the 1960's as part of other Nevada Test Site studies (Moore, 1961, 1962; Thordarson and others, 1967; Young, 1972; Winograd and Thordarson, 1975). Waddell (1982, 1984), Robison (1984), Waddell and others (1984), Robison and others (1988), Gemmel (1990), O'Brien (1991), Luckey and others (1993), Boucher (1994), LaCamera and Westenburg (1994), Hale and Westenburg (1995), O'Brien and others (1995), and Savard (1995) have presented groundwater-level data for wells in the Fortymile Wash and Yucca Mountain area since hydrologic characterization of the potential repository became a national concern. Squires and Young (1984), Pabst and others (1993), and Kane and others (1994) investigated streamflow in Fortymile Wash. Streamflow and precipitation data for the Fortymile Wash area collected during water years 1991-93 are included in a statewide report (Emett and others, 1994). Huber (1988) investigated the geomorphic evolution of Fortymile Wash. Osterkamp and others (1994) made ground-water recharge estimates in the Fortymile Wash drainage basin as part of their study of the Amargosa River Basin. Savard (1994) investigated ground-water recharge in Fortymile Canyon.

\section{Quality Assurance}

Data in this report will be used to evaluate the suitability of the Yucca Mountain site for a potential high-level nuclear-waste repository. Reliability in the collection, processing, and reporting of the hydrologic data is necessary so the data may be used with confidence to assess the expected performance of the potential repository. A quality-assurance program has been implemented to support the reliability of the data. The precipitation, neutron-logging, water-level, and water- quality data were all collected under a qualityassurance program.

The precipitation, neutron-logging profiles, and water-level and water-quality measurements were obtained by methods described by formal technical procedures as required by the quality-assurance program. The technical procedures included tests and adjustments performed during the measuring operation to ensure that the equipment was operating properly and that the expected precision and accuracy were attained. For example, the technical procedure to neutron $\log$ a borehole specifies how to perform standardization tests, log the borehole, and process the data.

\section{Acknowledgments}

Numerous personnel have helped in the collection, compilation, and quality assurance of the data included in this report. Those making notable specific contributions from Foothills Engineering, Inc., were Dale Ambos, Earl Christensen, and David Vohman for compiling the precipitation data; David Hudson and Kevin Ellett for compiling the neutron-logging data; and Gordon Buchanan for collecting field measurements and compiling the ground-water data.

\section{HYDROLOGIC DATA}

Precipitation readings and water-content profiles from two sites (UE-29 UZN\#91 and UE-29 UZN\#92), miscellaneous streamflow observations, depth-toground-water data from three sites (UE-29 a\#1, UE-29 a\#2, and UE-29 UZN\#91), and the chemical composition of water from one well site (UE-29 a\#1) and two streamflow sites (Delirium Canyon tributary and Pah Canyon tributary) in the Fortymile Wash drainage basin were collected to understand recharge processes.

\section{Precipitation Data}

Nonrecording precipitation wedges were mounted on posts near the neutron-access borehole sites, UE-29 UZN\#91 and UE-29 UZN\#92 (fig. 1) during water years 1993-94. Nonrecording canister precipitation gages were installed on the same posts on December 2, 1992. Differences between successive measurements were used to determine the amount of precipitation that fell in the intervening period between 
readings (tables $1-4$ ). Oil was added to the nonrecording gages to prevent evaporation of the collected precipitation. Antifreeze was added so snowfall would melt and to keep the precipitation from freezing, allowing precipitation measurements to be made during the winter.

Precipitation totals at both sites were generally lower for the wedge gage than the canister gages. Both gages were mounted on the same post approximately 6 in. apart with the orifices at the same elevation at a site. The wedge has a 2.3 - by 2.5 -in. rectangular orifice, with a total orifice area of $5.75 \mathrm{in}^{2}$. The canister gage has a 4.0-in.-diameter circular orifice, with a total orifice area of $12.57 \mathrm{in}^{2}$. Ambos, Flint, and Hevesi (1995) attribute the precipitation total differences to an increase in wind turbulence above the wedge orifice because of a combination of orifice shape and size.

Total precipitation measured with the wedges was $296 \mathrm{~mm}$ at UE-29 UZN\#91 and $277 \mathrm{~mm}$ at UE-29 UZN\#92 for water year 1993. Total precipitation measured with the canisters was $301 \mathrm{~mm}$ at UE-29 UZN\#91 and $284 \mathrm{~mm}$ at UE-29 UZN\#92 for the period December 2, 1992, to September 9, 1993. November 16, 1992, to March 29, 1993, was the wettest period of water year 1993, when a series of storms came across the Fortymile Wash drainage basin. During this period, 89 percent of the total annual precipitation at the UE-29 UZN\#91 site and 90 percent at the UE-29 UZN\#92 site was measured (fig. 2).

Total precipitation measured with the wedges was $104 \mathrm{~mm}$ at UE-29 UZN\#91 and $108 \mathrm{~mm}$ at UE-29 UZN\#92 for water year 1994. Total precipitation measured with the canisters was $123 \mathrm{~mm}$ at UE-29 UZN\#91 and $122 \mathrm{~mm}$ at UE-29 UZN\#92 for water year 1994. January 21, 1994, to February 28, 1994, was the wettest period of water year 1994, when a series of storms came across the Fortymile Wash drainage basin. During this period, 37 percent of the wedge and 36 percent of the canister annual precipitation at the UE-29 UZN\#91 site and 41 percent of the wedge and 39 percent of the canister annual precipitation at the UE-29 UZN\#92 site was measured (fig. 3).

\section{Streamflow Data}

Streamflow data were collected from a network of four continuous-recording gaging stations and three crest-stage gages in the lower Fortymile Wash drainage basin. Locations of the gages are shown in figure 1 and described in table 5. Periods of streamflow occurred during January 17-19, February 9, and February 23, 1993. Peak flow and mean daily discharge data at the gaging stations and crest-stage gages for water year 1993 are contained in a statewide report (Emett and others, 1994). This section of the report documents miscellaneous streamflow observations and evidence from field reconnaissance for the distances the streamflow traveled before infiltrating into the streambed sediments.

Fortymile Wash had several periods of streamflow during January 17-19, 1993. Streamflow originated in the headwaters of the Fortymile Wash drainage basin and went over the UE-29 UZN\#91 location. The streamflow received inflow from Pah Canyon and Delirium Canyon and then went through the Fortymile Wash at Narrows gage. The streamflow continued downstream, receiving inflow from Yucca Wash. The streamflow went down to approximately $2.5 \mathrm{~km}$ above the Fortymile Wash at J-13 gage.

Pah Canyon tributary had periods of streamflow during January 17-19, February 9, and February 23, 1993. The January 17-19 streamflow contributed to the Fortymile Wash streamflow. The February 9 and 23 streamflow were not very large and infiltrated into the streambed materials before reaching UE-29 UZN\#91, several hundred feet below the confluence of Pah Canyon tributary and Fortymile Wash. The February 23 streamflow was estimated to be $0.5 \mathrm{ft}^{3} / \mathrm{s}$ at 1405 , when a sample was taken for physical properties and chemical analysis.

Delirium Canyon tributary had periods of streamflow January 17-19, February 9, and February 23, 1993. The January 17-19 streamflow contributed to the Fortymile Wash streamflow. The gravel deposited from the February 12 and March 31, 1992, streamflow in a section of the stream (fig. 4) was mostly eroded away during the January 17-19, 1993, streamflow (fig. 5). The February 9 and 23 streamflow were not very large and infiltrated into the streambed materials within several hundred feet of the confluence of Delirium Canyon tributary and Fortymile Wash. The February 9 streamflow was estimated to be $0.5 \mathrm{ft}^{3} / \mathrm{s}$ at 1330 , when a sample was taken for physical properties and chemical analysis.

Yucca Wash had periods of streamflow on January 18,1993 . Two separate peak flows were recorded at the crest-stage gage near the mouth. The 
Table 1. Precipitation totals for the UE-29 UZN\#91 site, Yucca Mountain area, Nevada, during water year 1993

[in., inches; mm, millimeters; --, no data; WY, water year]

\begin{tabular}{|c|c|c|c|c|c|}
\hline \multicolumn{2}{|c|}{ Period } & \multicolumn{2}{|c|}{ Wedge gage totals } & \multicolumn{2}{|c|}{ Canister gage totals* } \\
\hline Begin date & End date & (in.) & $(\mathrm{mm})$ & (in.) & $(\mathrm{mm})$ \\
\hline Oct. 1, 1992 & Oct. 27,1992 & 0.18 & 5 & - & - \\
\hline Oct. 27,1992 & Nov. 2, 1992 & 0.28 & 7 & - & -- \\
\hline Nov. 2, 1992 & Nov. 16, 1992 & 0.00 & $\mathbf{0}$ & - & -- \\
\hline Nov. 16, 1992 & Dec. 9, 1992 & 2.11 & 54 & 1.99 & 51 \\
\hline Dec. 9, 1992 & Dec. 14,1992 & 0.05 & 1 & 0.07 & 2 \\
\hline Dec. 14,1992 & Dec. 29,1992 & 0.42 & 11 & 0.48 & 12 \\
\hline Dec. 29, 1992 & Jan. 5, 1993 & 0.19 & 5 & 0.10 & 2 \\
\hline Jan. 5, 1993 & Jan. 8, 1993 & 0.44 & 11 & 0.50 & 13 \\
\hline Jan. 8, 1993 & Jan. 14, 1993 & 1.00 & 25 & 1.13 & 29 \\
\hline Jan. 14, 1993 & Jan. 20, 1993 & 2.05 & 52 & 2.25 & 57 \\
\hline Jan. 20, 1993 & Feb. 1, 1993 & 0.10 & 2 & 0.13 & 3 \\
\hline Feb. 1, 1993 & Feb. 8, 1993 & 0.50 & 13 & 0.53 & 13 \\
\hline Feb. 8, 1993 & Feb. 9, 1993 & 0.70 & 18 & 0.75 & 19 \\
\hline Feb. 9, 1993 & Feb. 12, 1993 & 0.15 & 4 & 0.15 & 4 \\
\hline Feb. 12,1993 & Feb. 22,1993 & 0.60 & 15 & 0.68 & 17 \\
\hline Feb. 22, 1993 & Feb. 24, 1993 & 0.45 & 11 & 0.47 & 12 \\
\hline Feb. 24, 1993 & Mar. 1, 1993 & 0.50 & 13 & 0.59 & 15 \\
\hline Mar. 1, 1993 & Mar. 29, 1993 & 1.05 & 27 & 1.08 & 27 \\
\hline Mar. 29, 1993 & Jun. 7, 1993 & 0.63 & 16 & 0.73 & 18 \\
\hline Jun. 7, 1993 & Aug. 10, 1993 & 0.18 & 5 & 0.23 & 6 \\
\hline Aug. 10, 1993 & Aug. 30, 1993 & 0.03 & 1 & 0.04 & 1 \\
\hline \multirow[t]{2}{*}{ Aug. 30, 1993} & Sep. 9, 1993 & 0.00 & 0 & 0.00 & 0 \\
\hline & 1993 WY total & 11.61 & 296 & 11.90 & 301 \\
\hline
\end{tabular}

*4-in. canister installed December 2, 1992. 
Table 2. Precipitation totals for the UE-29 UZN\#91 site, Yucca Mountain area, Nevada, during water year 1994

[in., inches; mm, millimeters; WY, water year]

\begin{tabular}{|c|c|c|c|c|c|}
\hline \multicolumn{2}{|c|}{ Period } & \multicolumn{2}{|c|}{ Wodge gage totals } & \multicolumn{2}{|c|}{ Canister gage totals } \\
\hline Begin date & End date & (in.) & $(\mathbf{m m})$ & (in.) & $(\mathrm{mm})$ \\
\hline Sep. 9,1993 & Oct. 15,1993 & 0.49 & 12 & 0.55 & 14 \\
\hline Oct. 15, 1993 & Nov. 3, 1993 & 0.04 & 1 & 0.00 & 0 \\
\hline Nov. 3, 1993 & Nov. 9, 1993 & 0.00 & 0 & 0.00 & 0 \\
\hline Nov. 9, 1993 & Nov. 15,1993 & 0.15 & 4 & 0.22 & 6 \\
\hline Nov. 15,1993 & Nov. 22,1993 & 0.00 & 0 & 0.00 & 0 \\
\hline Nov. 22, 1993 & Dec. 2, 1993 & 0.29 & 7 & 0.35 & 9 \\
\hline Dec. 2,1993 & Dec. 7, 1993 & 0.01 & 0 & 0.00 & 0 \\
\hline Dec. 7, 1993 & Dec. 13,1993 & 0.20 & 5 & 0.27 & 7 \\
\hline Dec. 13, 1993 & Dec. 16,1993 & 0.26 & 7 & 0.29 & 7 \\
\hline Dec. 16, 1993 & Jan. 21,1994 & 0.00 & 0 & 0.00 & 0 \\
\hline Jan. 21, 1994 & Jan. 27,1994 & 0.64 & 16 & 0.62 & 16 \\
\hline Jan. 27, 1994 & Feb. 4, 1994 & 0.06 & 2 & 0.08 & 2 \\
\hline Feb. 4, 1994 & Feb. 10, 1994 & 0.55 & 14 & 0.64 & 16 \\
\hline Feb. 10, 1994 & Feb. 28, 1994 & 0.25 & 6 & 0.34 & 9 \\
\hline Feb. 28, 1994 & Mar. 10, 1994 & 0.01 & 0 & 0.02 & 1 \\
\hline Mar. 10, 1994 & Mar. 21, 1994 & 0.07 & 2 & 0.06 & 2 \\
\hline Mar. 21, 1994 & Mar. 30, 1994 & 0.25 & 6 & 0.29 & 7 \\
\hline Mar. 30, 1994 & Apr. 12, 1994 & 0.13 & 3 & 0.16 & 4 \\
\hline Apr. 12, 1994 & Apr. 28,1994 & 0.37 & 9 & 0.44 & 11 \\
\hline Apr. 28,1994 & Apr. 29,1994 & 0.08 & 2 & 0.09 & 2 \\
\hline Apr. 29, 1994 & May 12,1994 & 0.02 & 1 & 0.07 & 2 \\
\hline May 12,1994 & May 20, 1994 & 0.01 & 0 & 0.01 & 0 \\
\hline May 20, 1994 & Jun. 1, 1994 & 0.03 & 1 & 0.04 & 1 \\
\hline Jun. 1,1994 & Aug. 12, 1994 & 0.00 & 0 & 0.00 & 0 \\
\hline Aug. 12, 1994 & Sep. 15, 1994 & 0.14 & 4 & 0.14 & 4 \\
\hline Sep. 15,1994 & Sep. 29, 1994 & 0.06 & 2 & 0.13 & 3 \\
\hline \multirow[t]{2}{*}{ Sep. 29, 1994} & Oct. 12,1994 & 0.00 & 0 & 0.00 & 0 \\
\hline & 1994 WY total & 4.11 & 104 & 4.81 & 123 \\
\hline
\end{tabular}


Table 3. Precipitation totals for the UE-29 UZN\#92 site, Yucca Mountain area, Nevada, during water year 1993

[in., inches; mm, millimeters; --, no data; WY, water year]

\begin{tabular}{|c|c|c|c|c|c|}
\hline \multicolumn{2}{|c|}{ Period } & \multicolumn{2}{|c|}{ Wedge gage totals } & \multicolumn{2}{|c|}{ Canister gage totals* } \\
\hline Begin date & End date & (in.) & $(\mathrm{mm})$ & (in.) & $(\mathrm{mm})$ \\
\hline Oct. 1,1992 & Oct. 27,1992 & 0.10 & 2 & -- & -- \\
\hline Oct. 27,1992 & Nov. 2, 1992 & 0.53 & 13 & -- & -- \\
\hline Nov. 2, 1992 & Nov. 16, 1992 & 0.00 & 0 & -- & -- \\
\hline Nov. 16,1992 & Dec. 9, 1992 & 2.15 & 55 & 2.16 & 55 \\
\hline Dec. 9,1992 & Dec. 14,1992 & 0.10 & 2 & 0.07 & 2 \\
\hline Dec. 14, 1992 & Dec. 29, 1992 & 0.33 & 8 & 0.41 & 10 \\
\hline Dec. 29,1992 & Jan. 5,1993 & 0.12 & 3 & 0.03 & 1 \\
\hline Jan. 5, 1993 & Jan. 8, 1993 & 0.45 & 11 & 0.50 & 13 \\
\hline Jan. 8, 1993 & Jan. 14, 1993 & 0.90 & 23 & 0.96 & 24 \\
\hline Jan. 14,1993 & Jan. 20, 1993 & 1.55 & 39 & 1.70 & 43 \\
\hline Jan. 20, 1993 & Feb. 1, 1993 & 0.08 & 2 & 0.13 & 3 \\
\hline Feb. 1, 1993 & Feb. 8, 1993 & 0.50 & 13 & 0.57 & 14 \\
\hline Feb. 8, 1993 & Feb. 9, 1993 & 0.65 & 17 & 0.67 & 17 \\
\hline Feb. 9, 1993 & Feb. 12, 1993 & 0.05 & 1 & 0.07 & 2 \\
\hline Feb. 12, 1993 & Feb. 22, 1993 & 0.55 & 14 & 0.61 & 15 \\
\hline Feb. 22, 1993 & Feb. 24, 1993 & 0.88 & 22 & 0.98 & 25 \\
\hline Feb. 24, 1993 & Mar. 1, 1993 & 0.50 & 13 & 0.53 & 13 \\
\hline Mar. 1, 1993 & Mar. 29, 1993 & 1.02 & 26 & 1.17 & 30 \\
\hline Mar. 29, 1993 & Jun. 7, 1993 & 0.43 & 11 & 0.49 & 12 \\
\hline Jun. 7, 1993 & Aug. 10, 1993 & 0.06 & 1 & 0.11 & 3 \\
\hline Aug. 10, 1993 & Aug. 30, 1993 & 0.05 & 1 & 0.09 & 2 \\
\hline Aug. 30, 1993 & Sep. 9, 1993 & 0.00 & 0 & 0.00 & 0 \\
\hline & 1993 WY total & 11.00 & 277 & 11.25 & 284 \\
\hline
\end{tabular}

*4-in. canister installed December 2, 1992. 
Table 4. Precipitation totals for the UE-29 UZN\#92 site, Yucca Mountain area, Nevada, during water year 1994

[in., inches; mm, millimeters; WY, water year]

\begin{tabular}{|c|c|c|c|c|c|}
\hline \multicolumn{2}{|c|}{ Period } & \multicolumn{2}{|c|}{ Wedge gage totals } & \multicolumn{2}{|c|}{ Canister gage totals } \\
\hline Begin date & End date & (in.) & $(\mathbf{m m})$ & (in.) & $(\mathrm{mm})$ \\
\hline Sep. 9, 1993 & Oct. 15,1993 & 0.44 & 11 & 0.50 & 13 \\
\hline Oct. 15,1993 & Nov. 3, 1993 & 0.02 & 1 & 0.00 & 0 \\
\hline Nov. 3, 1993 & Nov. 9, 1993 & 0.00 & 0 & 0.00 & 0 \\
\hline Nov. 9, 1993 & Nov. 15, 1993 & 0.10 & 3 & 0.16 & 4 \\
\hline Nov. 15, 1993 & Nov. 22, 1993 & 0.00 & $\mathbf{0}$ & 0.00 & 0 \\
\hline Nov. 22, 1993 & Dec. 2,1993 & 0.29 & 7 & 0.30 & 8 \\
\hline Dec. 2, 1993 & Dec. 7,1993 & 0.01 & 0 & 0.00 & $\mathbf{0}$ \\
\hline Dec. 7, 1993 & Dec. 13, 1993 & 0.17 & 4 & 0.25 & 6 \\
\hline Dec. 13, 1993 & Dec. 16, 1993 & 0.30 & 8 & 0.35 & 9 \\
\hline Dec. 16, 1993 & Jan. 21, 1994 & 0.00 & 0 & 0.00 & 0 \\
\hline Jan. 21, 1994 & Jan. 27, 1994 & 0.80 & 20 & 0.73 & 19 \\
\hline Jan. 27, 1994 & Feb. 4, 1994 & 0.06 & 2 & 0.08 & 2 \\
\hline Feb. 4, 1994 & Feb. 10, 1994 & 0.57 & 14 & 0.62 & 16 \\
\hline Feb. 10, 1994 & Feb. 28, 1994 & 0.35 & 9 & 0.40 & 10 \\
\hline Feb. 28,1994 & Mar. 10, 1994 & 0.01 & 0 & 0.01 & 0 \\
\hline Mar. 10, 1994 & Mar. 21, 1994 & 0.06 & 2 & 0.05 & 1 \\
\hline Mar. 21, 1994 & Mar. 30, 1994 & 0.22 & 6 & 0.27 & 7 \\
\hline Mar. 30, 1994 & Apr. 12, 1994 & 0.17 & 4 & 0.15 & 4 \\
\hline Apr. 12, 1994 & Apr. 28, 1994 & 0.45 & 11 & 0.55 & 14 \\
\hline Apr. 28, 1994 & Apr. 29,1994 & 0.01 & 0 & 0.01 & 0 \\
\hline Apr. 29, 1994 & May 12,1994 & 0.02 & 1 & 0.06 & 2 \\
\hline May 12,1994 & May 20, 1994 & 0.06 & 2 & 0.09 & 2 \\
\hline May 20, 1994 & Jun. 1, 1994 & 0.02 & 1 & 0.04 & 1 \\
\hline Jun. 1, 1994 & Aug. 12, 1994 & 0.00 & 0 & 0.00 & 0 \\
\hline Aug. 12, 1994 & Sep. 15,1994 & 0.00 & 0 & 0.00 & 0 \\
\hline Sep. 15, 1994 & Sep. 29,1994 & 0.09 & 2 & 0.14 & 4 \\
\hline \multirow[t]{2}{*}{ Sep. 29, 1994} & Oct. 12,1994 & 0.00 & 0 & 0.00 & 0 \\
\hline & $1994 \mathrm{WY}$ total & 4.22 & 108 & 4.76 & 122 \\
\hline
\end{tabular}




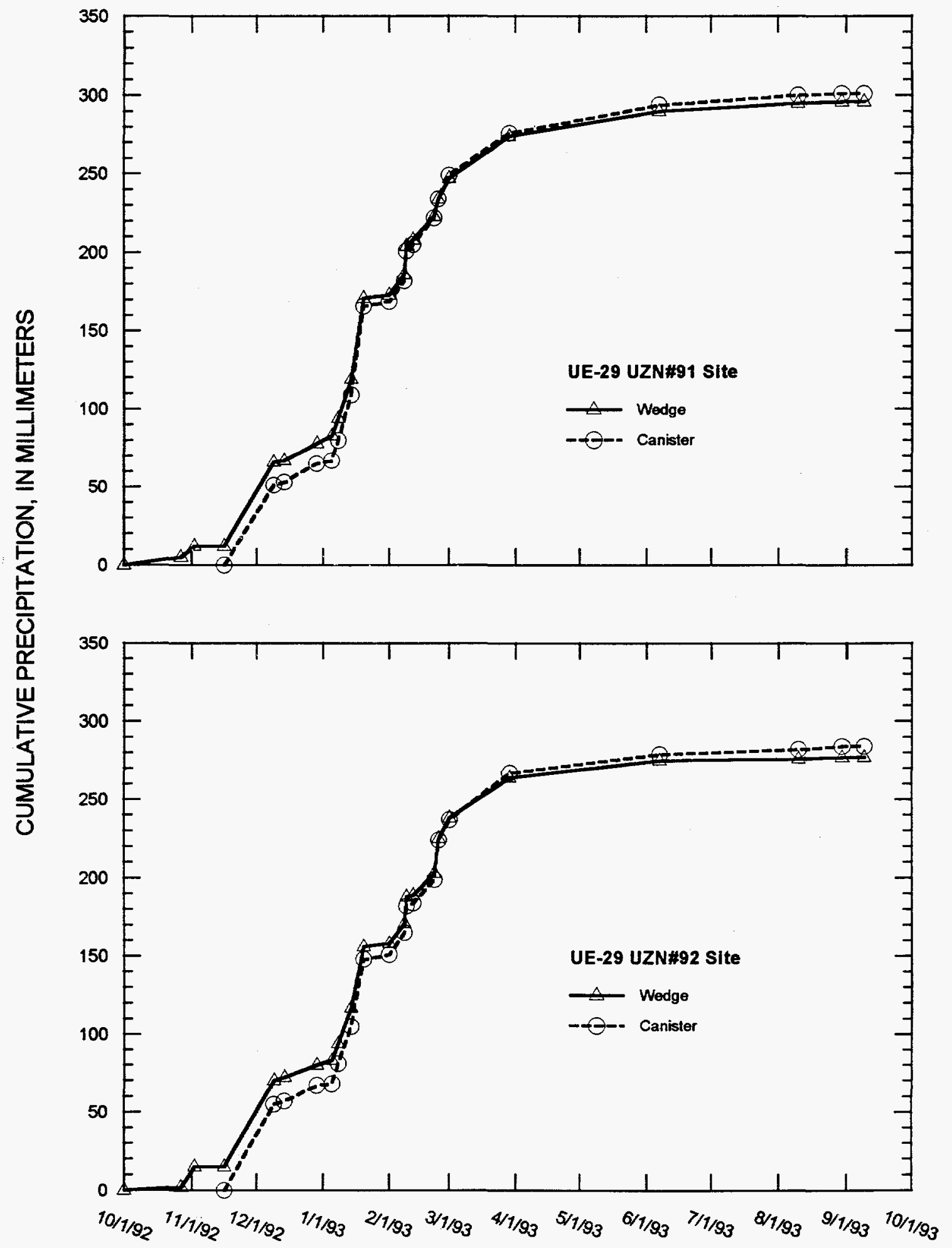

Figure 2. Cumulative precipitation at UE-29 UZN\#91 and UE-29 UZN\#92 sites in the Yucca Mountain area, Nevada, during water year 1993. 


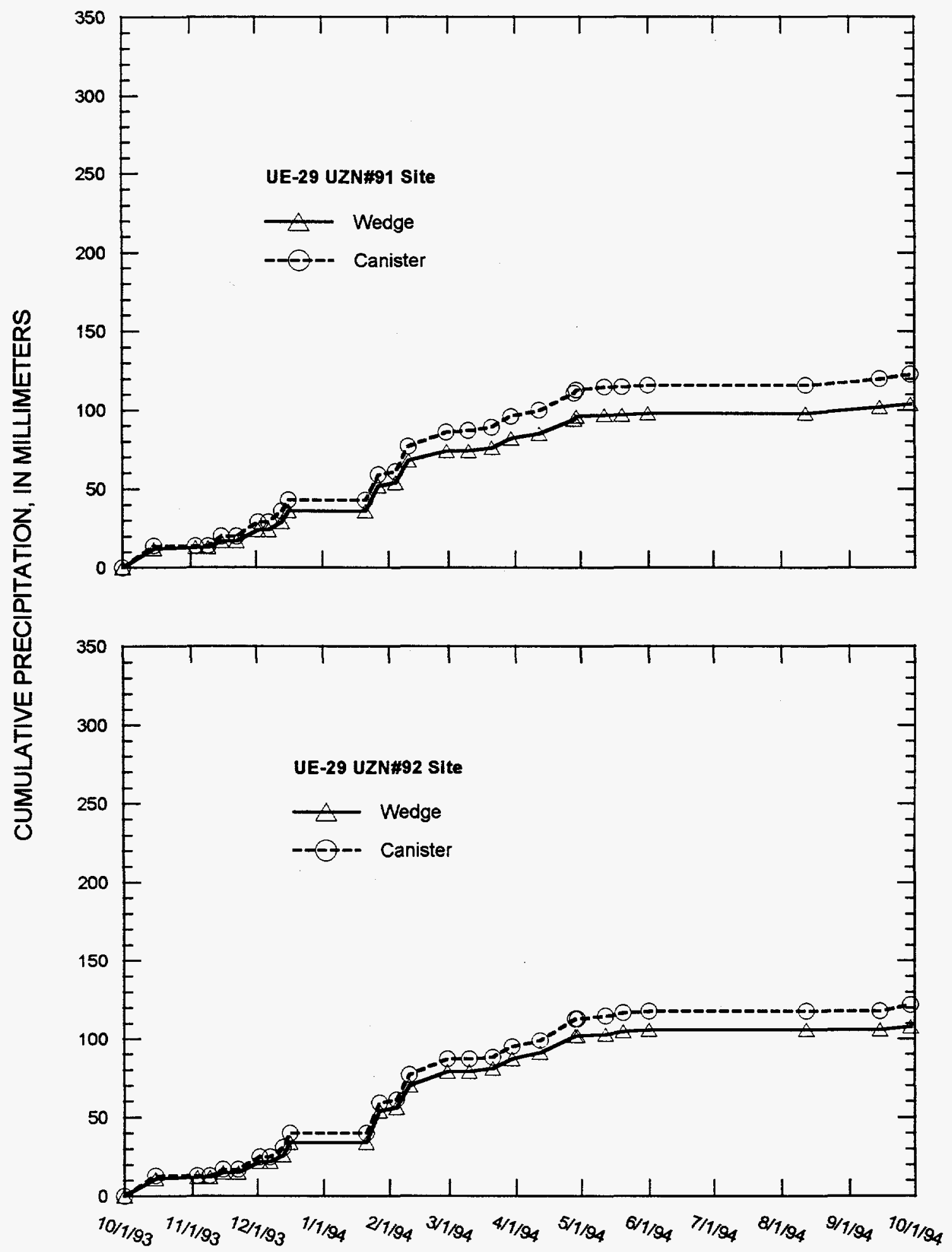

Figure 3. Cumulative precipitation at UE-29 UZN\#91 and UE-29 UZN\#92 sites in the Yucca Mountain area, Nevada, during water year 1994. 
Table 5. Gaging station and crest-stage locations in the Yucca Mountain area, Nevada

$\left[\mathrm{mi}^{2}\right.$, square miles; $\mathrm{G}$, continuous-recording gaging station; $\mathrm{C}$, crest-stage gage]

\begin{tabular}{|c|c|c|c|c|c|}
\hline \multirow{2}{*}{$\begin{array}{l}\text { Station } \\
\text { number }\end{array}$} & \multirow{2}{*}{ Station name } & \multicolumn{2}{|c|}{ Location } & \multirow{2}{*}{$\begin{array}{l}\text { Gage } \\
\text { type }\end{array}$} & \multirow{2}{*}{$\begin{array}{c}\text { Drainage } \\
\text { area } \\
\left(\mathbf{m i}^{2}\right)\end{array}$} \\
\hline & & Latitude & Longitude & & \\
\hline 10251250 & Fortymile Wash at Narrows, Nevada Test Site, Nevada & $36^{\circ} 53^{\prime} 13^{\prime \prime}$ & $116^{\circ} 22^{\prime} 50^{\prime \prime}$ & $\mathbf{G}$ & 258 \\
\hline 10251252 & Yucca Wash near mouth, Nevada Test Site, Nevada & $36^{\circ} 51^{\prime} 58^{\prime \prime}$ & $116^{\circ} 23^{\prime} 38^{\prime \prime}$ & C & 17.0 \\
\hline 102512533 & Pagany Wash \#1 near well UZ-4, Nevada Test Site, Nevada & $36^{\circ} 51^{\prime} 39^{\prime \prime}$ & $116^{\circ} 26^{\prime} 08^{\prime \prime}$ & $\mathbf{G}$ & 0.82 \\
\hline 10251254 & Drillhole Wash at mouth, Nevada Test Site, Nevada & $36^{\circ} 49^{\prime} 13^{\prime \prime}$ & $116^{\circ} 23^{\prime} 52^{\prime \prime}$ & $\mathrm{C}$ & 16.3 \\
\hline 10251255 & Fortymile Wash near well J-13, Nevada Test Site, Nevada & $36^{\circ} 48^{\prime} 27^{\prime \prime}$ & $116^{\circ} 24^{\prime} 01^{\prime \prime}$ & G & 304 \\
\hline 10251256 & Dune Wash near Busted Butte, Nevada Test Site, Nevada & $36^{\circ} 47^{\prime} 35^{\prime \prime}$ & $116^{\circ} 24^{\prime} 29^{\prime \prime}$ & $\mathbf{C}$ & 6.77 \\
\hline 10251258 & Fortymile Wash near Amargosa Valley, Nevada & $36^{\circ} 40^{\prime} 18^{\prime \prime}$ & $116^{\circ} 26^{\prime} 03^{\prime \prime}$ & $\mathbf{G}$ & 316 \\
\hline
\end{tabular}

streamflow went to Fortymile Wash and joined the Fortymile Wash streamflow.

No streamflow was recorded at the gaging stations, Fortymile Wash near well J-13 and Fortymile Wash near Amargosa Valley; or at the crest-stage gages, Drillhole Wash at mouth and Dune Wash near Busted Butte, during water year 1993. No streamflow was recorded at any of the gaging stations or creststage gages during water year 1994.

\section{Unsaturated-Zone Water-Content Profiles}

The water content of the unsaturated zone was monitored by neutron logging at UE-29 UZN\#91 and UE-29 UZN\#92, which are both located in the main Fortymile Wash channel. UE-29 UZN\#91 was drilled to a depth of $28.6 \mathrm{~m}$ and UE-29 UZN\#92 to $36.6 \mathrm{~m}$ (table 6). A measurement point was established at each neutron-access borehole so successive neutron logs could be compared. The UE-29 UZN\#91 measurement point is the top of the well casing with the cover removed, approximately $0.9 \mathrm{~m}$ above land surface. The UE-29 UZN\#92 measurement point is the top of the well casing with the cover removed, approximately $0.7 \mathrm{~m}$ above the land surface. Only the water content of the alluvium and colluvium was monitored in UE-29 UZN\#91, because the contact with the underlying volcanic bedrock is at $20.4 \mathrm{~m}$ below the measurement point (Blout and others, 1994), which is below the water table. The alluvium and colluvium contact with the underlying volcanic bedrock is at $18.3 \mathrm{~m}$ below the measurement point in UE-29 UZN\#92, so the vertical water-content profiles represent conditions in the allu- vium, colluvium, and the volcanic bedrock to a depth of $19.4 \mathrm{~m}$.

The hand-held neutron-logging system outputs the number of counts, which are proportional to the water content of the surrounding geologic medium (Gardner, 1986). The system has a resolution distance of less than $1 \mathrm{~m}$, thus the moisture contents derived represent only a small portion of the study area. Repeat measurements over the same intervals and depths allow for comparison of changes in moisture content. The neutron-logging tool was hand lowered into the neutron-access borehole with a depth-marked cable allowing vertical profiles of the water content to be made throughout the year (figs. 6 and 7). Neutron counts were recorded every $0.1 \mathrm{~m}$ from land surface to $5 \mathrm{~m}$ below the measurement point and then every $0.3 \mathrm{~m}$. Neutron counts were converted to volumetric water content using a calibration equation. The calibration equation and volumetric water-content readings for each depth are stored in Yucca Mountain Project data bases. Readings at UE-29 UZN\#91 were stopped at varying depths to prevent the neutron tool from becoming immersed in the ground water and damaging the tool. Readings at UE-29 UZN\#92 were stopped at 19.4-m depth. Generally both neutron-access boreholes were logged on the same day except for January 15,1993 , when only UE-29 UZN\#92 was logged, and February 12, 1993, when only UE-29 UZN\#91 was logged.

At UE-29 UZN\#91, there were no major differences from October 8, 1992, to December 11, 1992 , in the volumetric water-content profiles except for a slight increase in the upper $1.0 \mathrm{~m}$. After the January 17-19, 1993, period of streamflow, the 


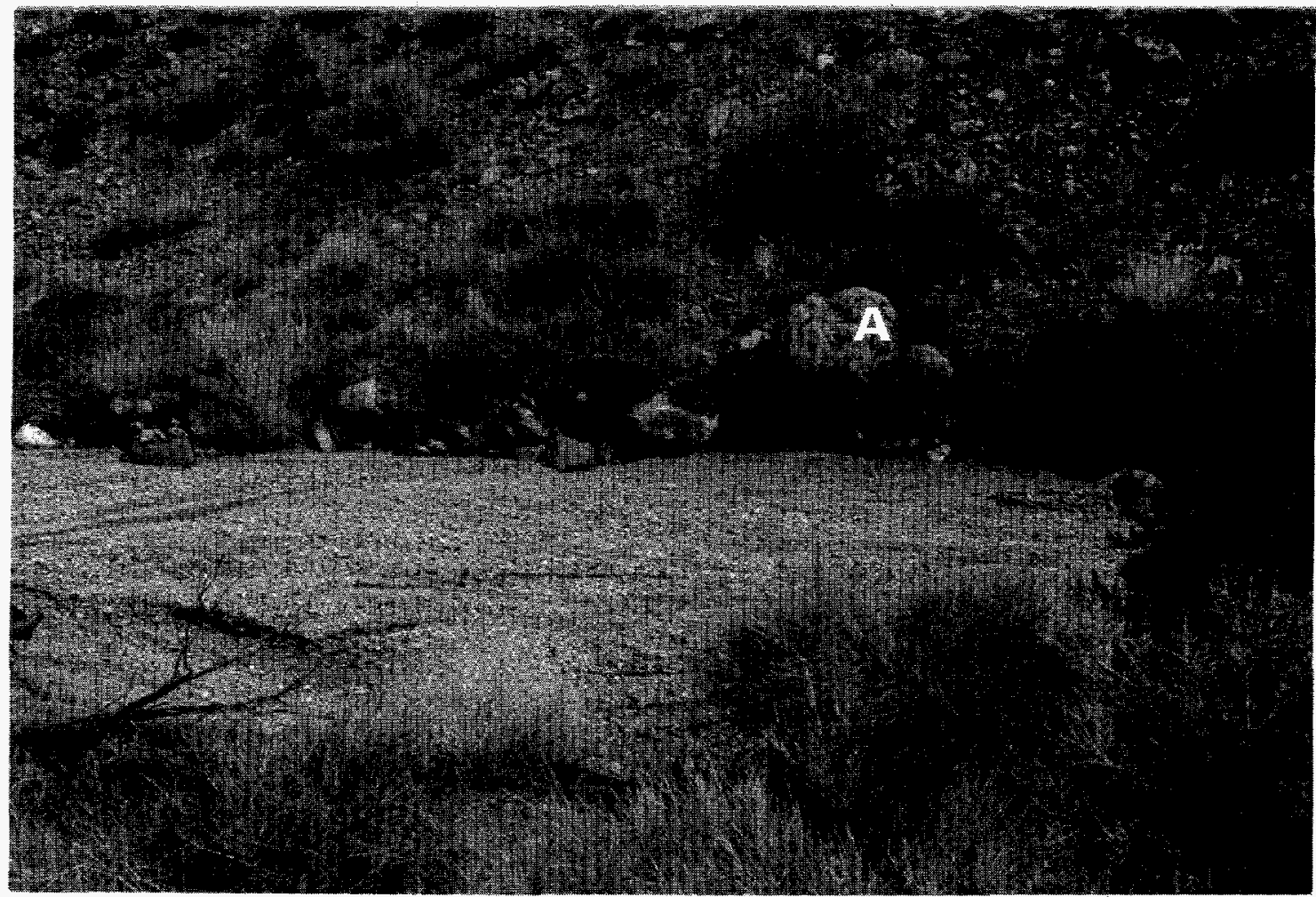

Figure 4. Delirium Canyon tributary velocity section in the Yucca Mountain area, Nevada, on March 31, 1992 (from Savard, 1995, fig. 5). A, reference point.

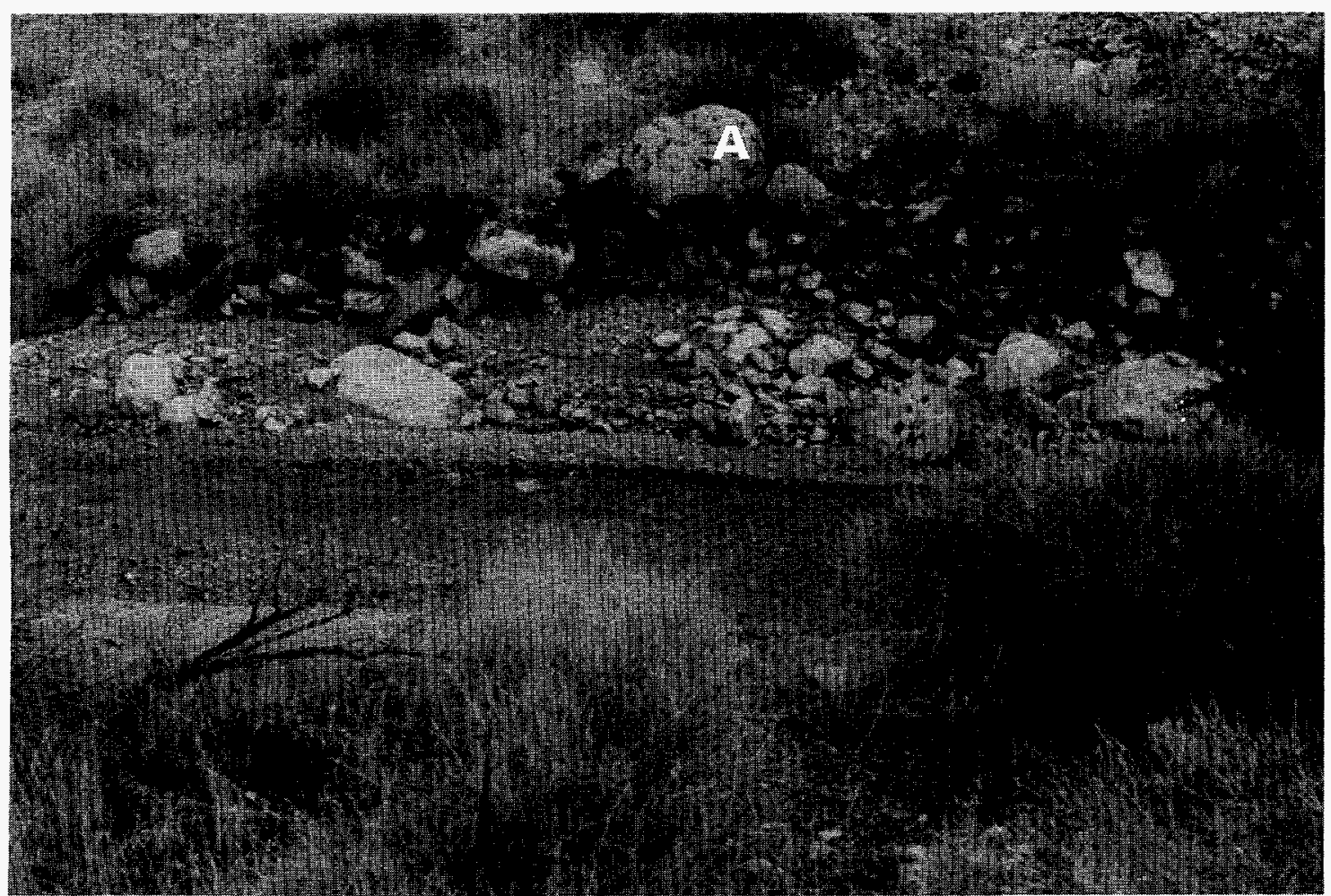

Figure 5. Delirium Canyon tributary velocity section in the Yucca Mountain area, Nevada, on January 19, 1993. A, reference point. 
Table 6. Well and neutron-access borehole locations in the Yucca Mountain area, Nevada

\begin{tabular}{lccccc}
\hline \multirow{2}{*}{ Name } & \multirow{2}{*}{ Site ID } & \multicolumn{2}{c}{ Location } & \multicolumn{2}{c}{$\begin{array}{c}\text { Depth of open interval } \\
\text { below land surface }\end{array}$} \\
\cline { 3 - 6 } & & Latitude & Longitude & $\begin{array}{c}\text { Top } \\
\text { (meters) }\end{array}$ & $\begin{array}{c}\text { Bottom } \\
\text { (meters) }\end{array}$ \\
\hline UE-29 a\#1 & 365629116222601 & $36^{\circ} 56^{\prime} 29^{\prime \prime}$ & $116^{\circ} 22^{\prime} 26^{\prime \prime}$ & 10.7 & 65.5 \\
UE-29 a\#2 & 365629116222602 & $36^{\circ} 56^{\prime 2} 29^{\prime \prime}$ & $116^{\circ} 22^{\prime} 26^{\prime \prime}$ & 86.9 & 213 \\
& & & & 247 & 421 \\
UE-29 UZN\#91 & 365624116222901 & $36^{\circ} 56^{\prime} 24^{\prime \prime}$ & $116^{\circ} 22^{\prime 2} 29^{\prime \prime}$ & 27.1 & 28.6 \\
UE-29 UZN\#92 & 365324116225101 & $36^{\circ} 53^{\prime} 14^{\prime \prime}$ & $116^{\circ} 22^{\prime} 51^{\prime \prime}$ & 32.0 & 36.6 \\
J-13 & 364829116234001 & $36^{\circ} 48^{\prime} 28^{\prime \prime}$ & $116^{\circ} 23^{\prime} 40^{\prime \prime}$ & 304 & 424 \\
& & & & 820 & 1,010 \\
J-12 & 364554116232401 & $36^{\circ} 45^{\prime} 54^{\prime \prime}$ & $116^{\circ} 23^{\prime 2} 24^{\prime \prime}$ & 265 & 347 \\
JF-3 & 364528116232201 & $36^{\circ} 45^{\prime 2} 28^{\prime \prime}$ & $116^{\circ} 23^{\prime 2} 22^{\prime \prime}$ & 224 & 347 \\
\hline
\end{tabular}

January 19, 1993, profile increased in water content relative to the December 11, 1992, profile from a depth of 0.7 to $12 \mathrm{~m}$. From January 19 to January 23, 1993, the profile decreased in water content from a depth of 0.7 to $12.5 \mathrm{~m}$, and increased from 12.5 to $15.5 \mathrm{~m}$, the approximate depth of the water table. From January 23, 1993, to September 15, 1994, the entire profile generally decreased or remained constant in water content.

At UE-29 UZN\#92, there were no major differences from October 8, 1992, to January 15,1993 , in the volumetric water-content profiles except for a slight increase in the upper $1.0 \mathrm{~m}$. After the January 17-19, 1993, period of streamflow, the January 19, 1993, profile increased in water content relative to the December 11, 1992, profile from a depth of 0.7 to $6.5 \mathrm{~m}$. From January 19,1993 , to January 26,1993 , the profile decreased in water content from a depth of 0.7 to $6.5 \mathrm{~m}$ and increased from 6.5 to $8 \mathrm{~m}$. From January 26, 1993, to September 15, 1994, the entire profile generally decreased or remained constant in water content.

\section{Depth-to-Water Data}

Depth-to-water measurements were made in two wells, UE-29 a\#1 and UE-29 a\#2, and one neutronaccess borehole, UE-29 UZN\#91, during water years 1993-94 (tables 7-9). These wells and the neutronaccess borehole are either in or near Fortymile Wash. Depth-to-water measurements were made in three other wells near Fortymile Wash, J-12, J-13, and JF-3, during water years 1993-94 but are reported in other publications (Hale and Westenburg, 1995).

A measurement point was established at each well so successive depth-to-water measurements could be compared. The UE-29 a\#1 measurement point is a scribed point on the top of the well cover, approximately $0.09 \mathrm{~m}$ above land surface. The UE-29 a\#2 measurement point is a scribed point on the well cover, approximately $0.1 \mathrm{~m}$ above the land surface. The UE-29 UZN\#91 measurement point is the same as for the neutron logging, the top of the well casing with the cover removed, approximately $0.9 \mathrm{~m}$ above the land surface. The land surface around UE-29 UZN\#91 is not stable because of erosion and deposition of stream sediments in the channel. Because measurement point elevations are not known to an adequate accuracy, the depth-to-water measurements have not been converted to an elevation with reference to mean sea level.

The measurements were made with a hand-held steel tape, an electric tape, or both. Both the steel tape and the electric tape use feet as a measurement scale. The steel tape measurements were made by lowering a steel tape into the well and holding at the measurement point a known depth on the tape. When the tape was removed from the well, the water cut was read. The water cut is the portion of the tape wetted by water in the well. Subtraction of the water cut from the hold results in the depth to water for the well below the measurement point at the measurement time. The electric tape measurements were made by lowering the probe in the well until the contacts in the probe just touched 

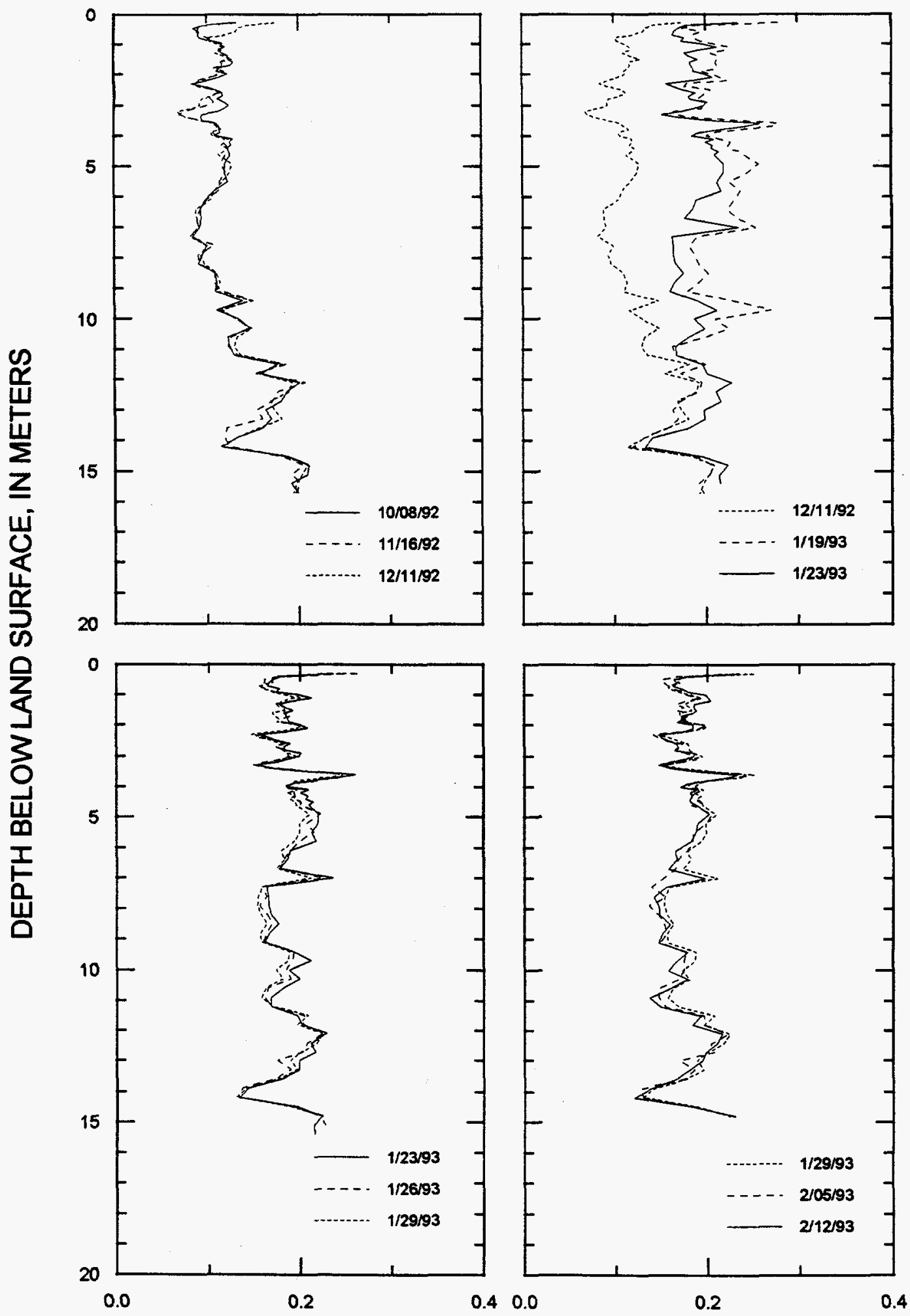

VOLUMETRIC WATER CONTENT, IN CUBIC CENTIMETER PER CUBIC CENTIMETER

Figure 6. Volumetric water-content profiles for UE-29 UZN\#91 in the Yucca Mountain area, Nevada. 

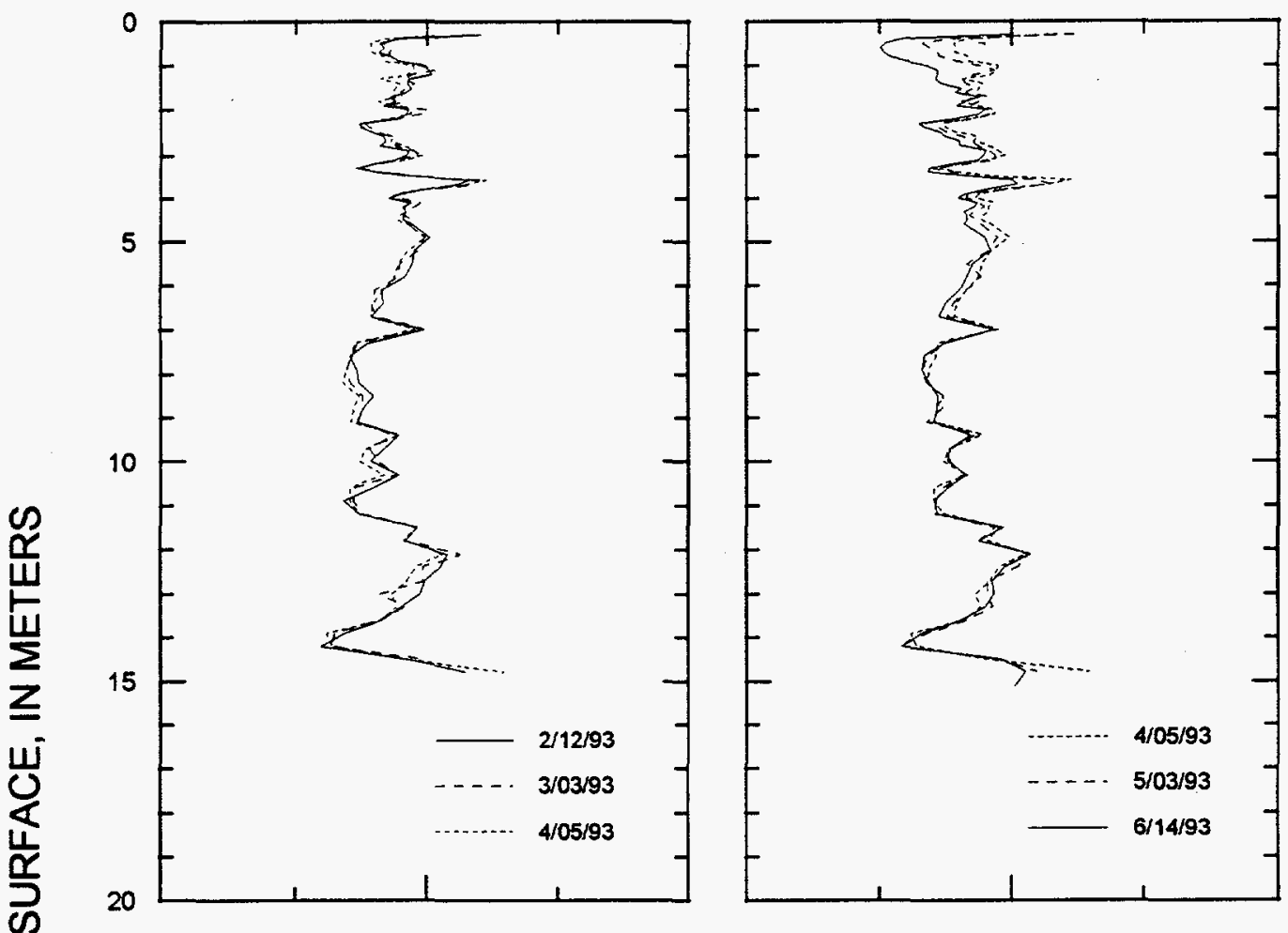

是
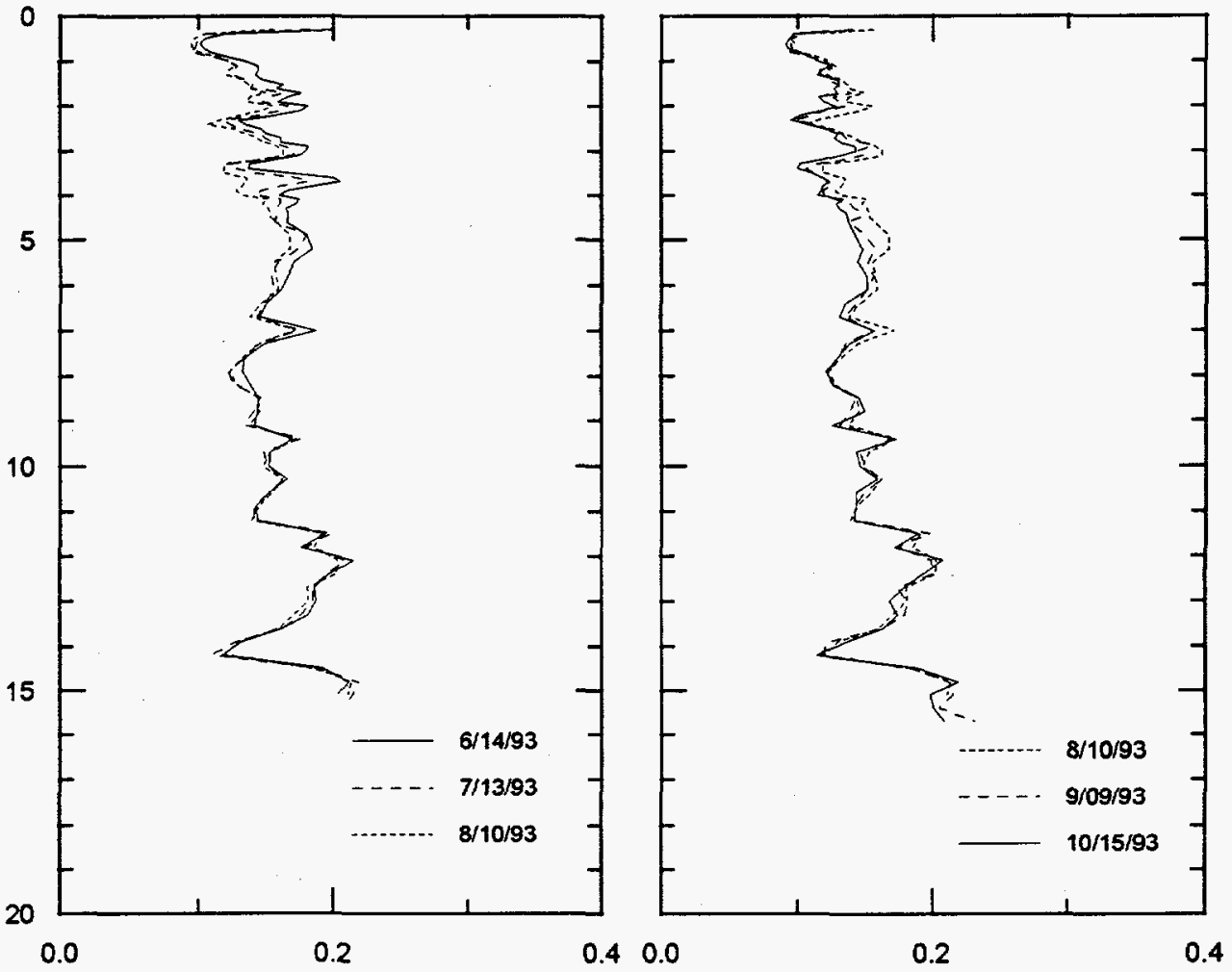

VOLUMETRIC WATER CONTENT, IN CUBIC CENTIMETER PER CUBIC CENTIMETER

Figure 6. Volumetric water-content profiles for UE-29 UZN\#91 in the Yucca Mountain area, Nevada--Continued. 

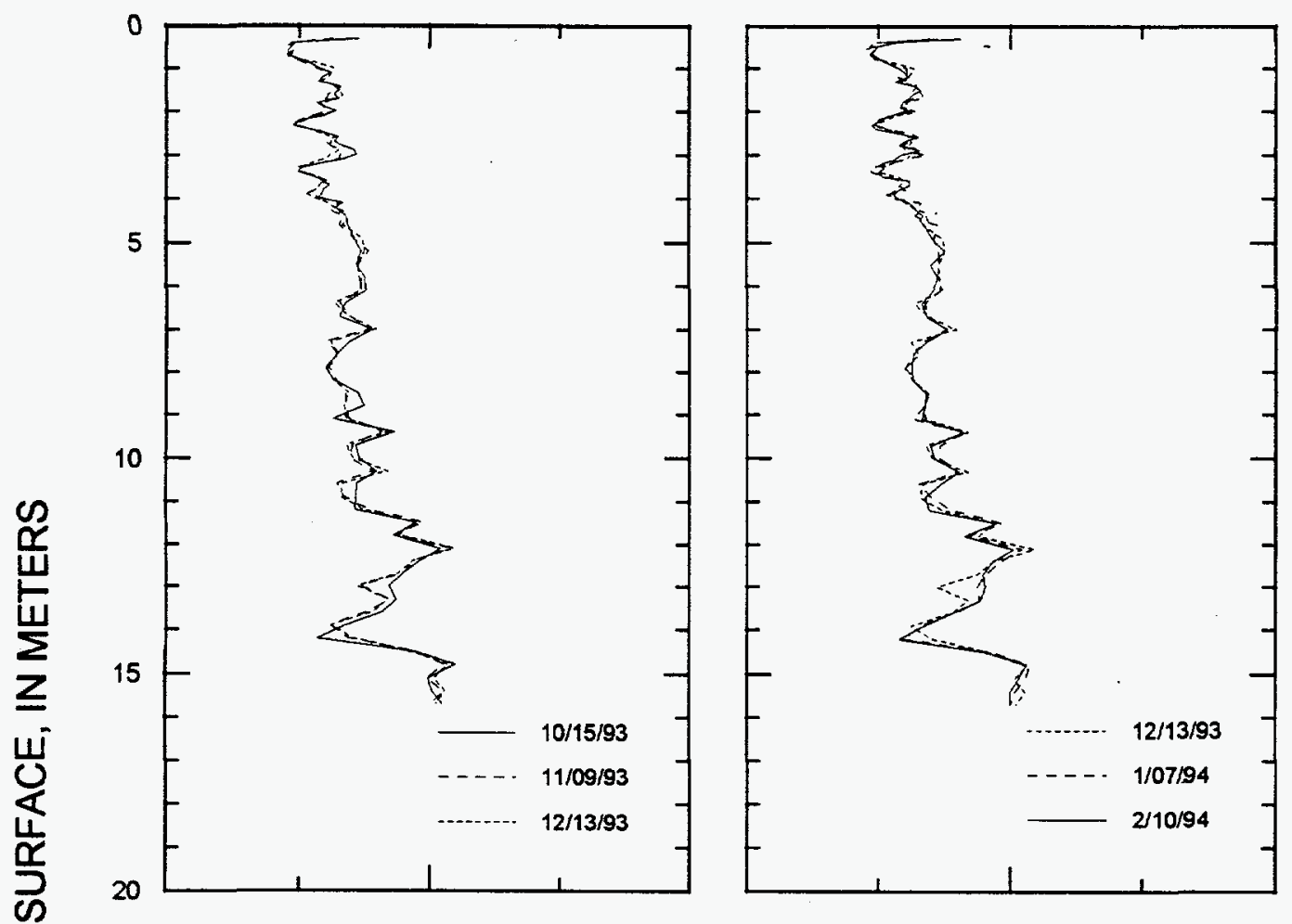

是
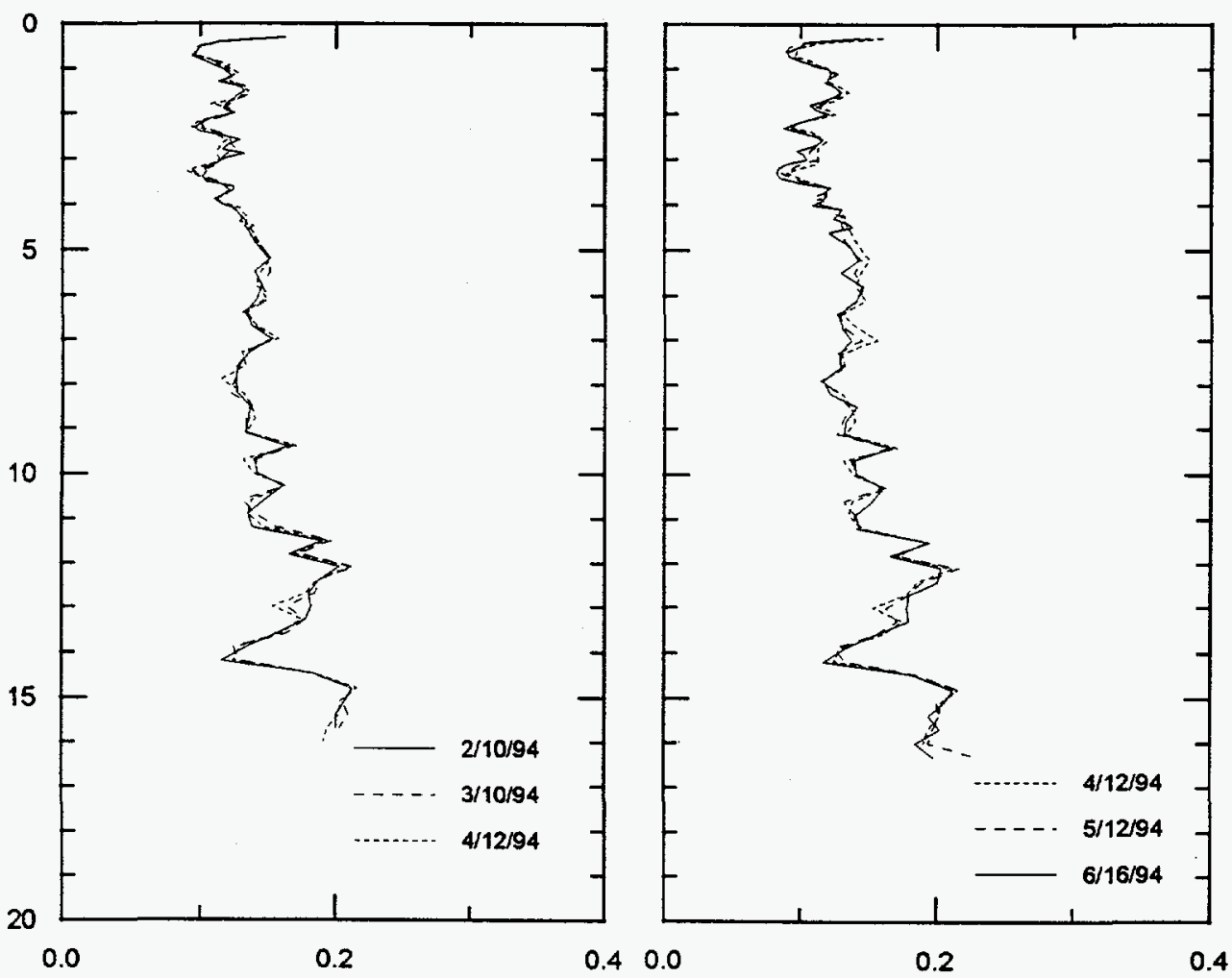

VOLUMETRIC WATER CONTENT, IN CUBIC CENTIMETER PER CUBIC CENTIMETER

Figure 6. Volumetric water-content profiles for UE-29 UZN\#91 in the Yucca Mountain area, Nevada--Continued. 

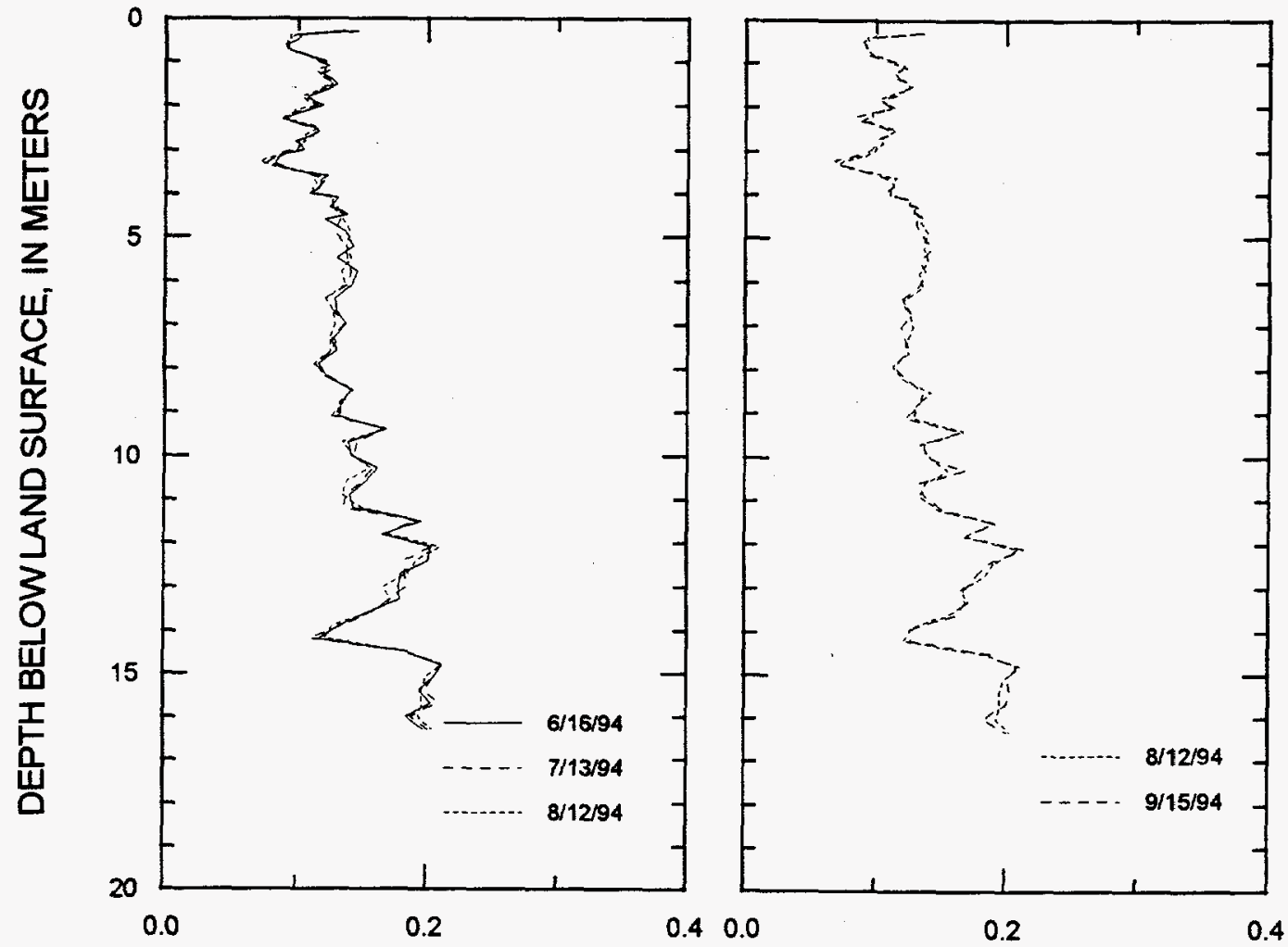

\section{VOLUMETRIC WATER CONTENT, IN CUBIC CENTIMETER PER CUBIC CENTIMETER}

Figure 6. Volumetric water-content profiles for UE-29 UZN\#91 in the Yucca Mountain area, Nevada--Continued.

the water. When the contacts touch the water, an electrical circuit is completed and visual and audio devices signal the contacts are in the water. Depth to water could be read directly from the electric tape because the water cut was at a reading of $0.00 \mathrm{ft}$. When both measurement techniques were used, the steel tape was the method used to report the depth-to-water measurement. Depth-to-water measurements were converted from feet to meters for reporting purposes.

Depth to water decreased after the January and February periods of streamflow in all three wells, indicating a rise in water levels. The measuring frequency was varied to document changes in the water levels (figs. 8-10). Wells UE-29 a\#1 and UE-29 a\#2 are only $10 \mathrm{~m}$ apart and have depth-to-water measurements that generally differ by $3 \mathrm{~m}$, with UE-29 a\#1 having the smaller depth to water. This is because the wells are open to different intervals of the geologic strata. The depth to the open intervals of the wells are listed in table 6. Well UE-29 a\#2 is open to the deepest interval of the three wells in the Pah Canyon area.
The highest water level in UE-29 a\#1 was on February 14, 1993, when a depth to water of $23.41 \mathrm{~m}$ was measured. The lowest water level was on January 11, 1993, when a depth to water of $27.30 \mathrm{~m}$ was measured. The observed range in water level was $3.89 \mathrm{~m}$ for water years 1993-94. Water levels were in a decreasing trend from October 1, 1992, to January 11, 1993. After the January 17-19, 1993, period of streamflow, the ground-water level rose $2.94 \mathrm{~m}$ in 7 to 9 days until January 26,1993 . Water levels then decreased until February 9, 1993. After the February 9, 1993, streamflow, the ground-water level rose $1.27 \mathrm{~m}$ in 5 days until February 14,1993 . Water levels then decreased until February 24, 1993. After the February 23, 1993, streamflow, the ground-water level rose $0.06 \mathrm{~m}$ in 8 days until March 3, 1993. Water levels then generally decreased until September 29, 1994.

The highest water level in UE-29 a\#2 occurred on three days (March 3, 8, and 10,1993) when a depth to water of $26.41 \mathrm{~m}$ was measured. The lowest water level was on January 11, 1993, when a depth to water 


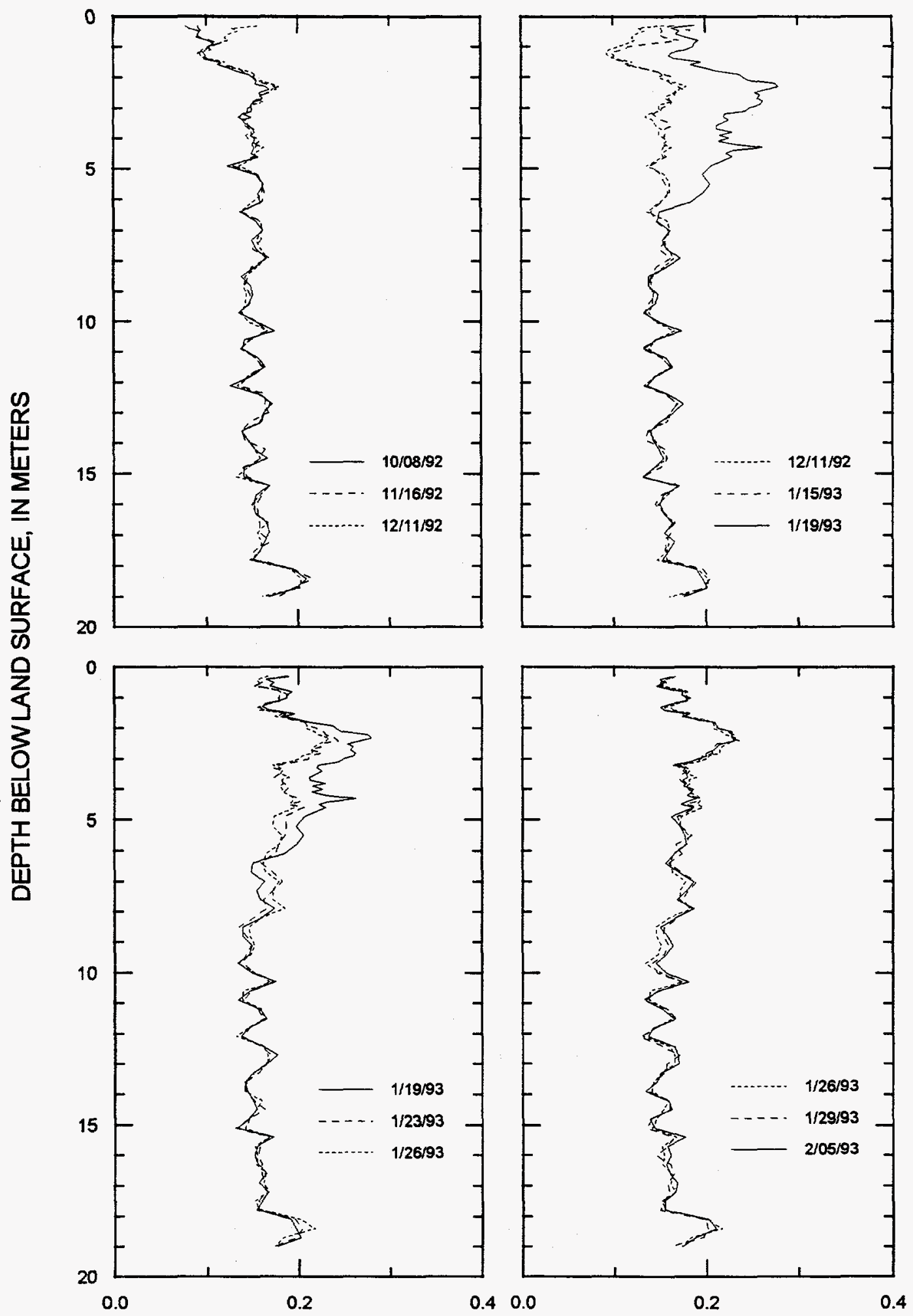

VOLUMETRIC WATER CONTENT, IN CUBIC CENTIMETER PER CUBIC CENTIMETER

Figure 7. Volumetric water-content profiles for UE-29 UZN\#92 in the Yucca Mountain area, Nevada. 

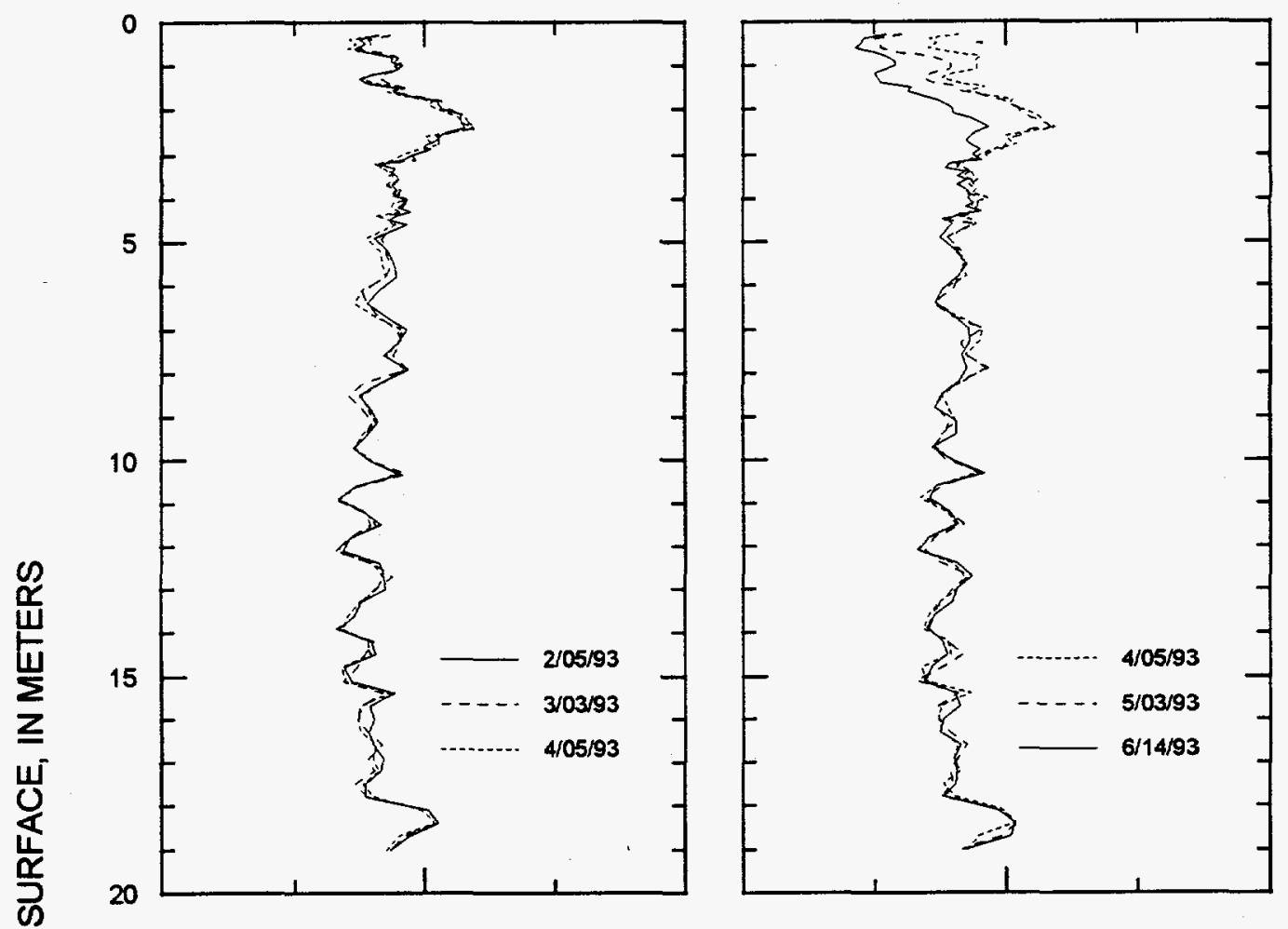

岁
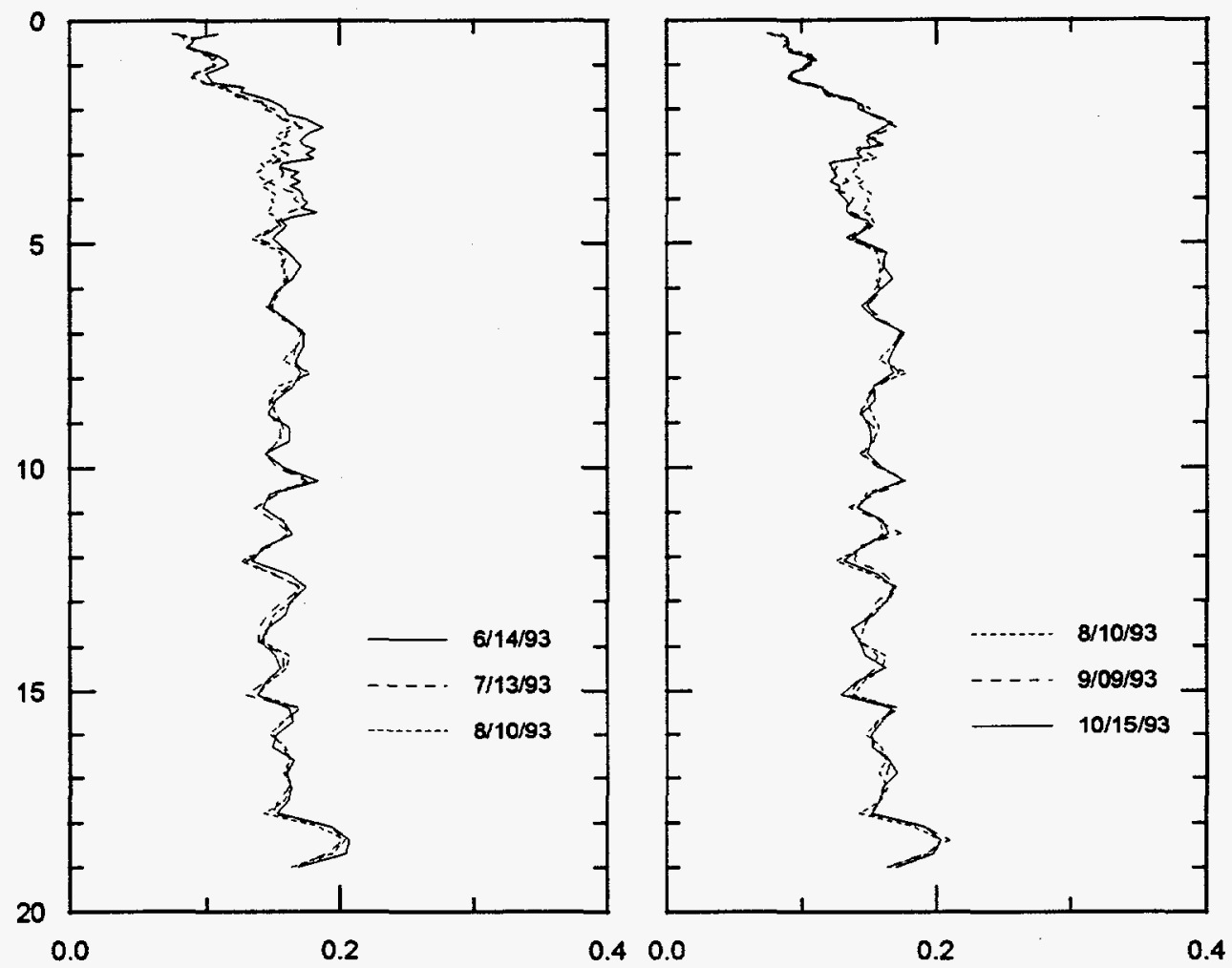

VOLUMETRIC WATER CONTENT, IN CUBIC CENTIMETER PER CUBIC CENTIMETER

Figure 7. Volumetric water-content profiles for UE-29 UZN\#92 in the Yucca Mountain area, Nevada--Continued. 


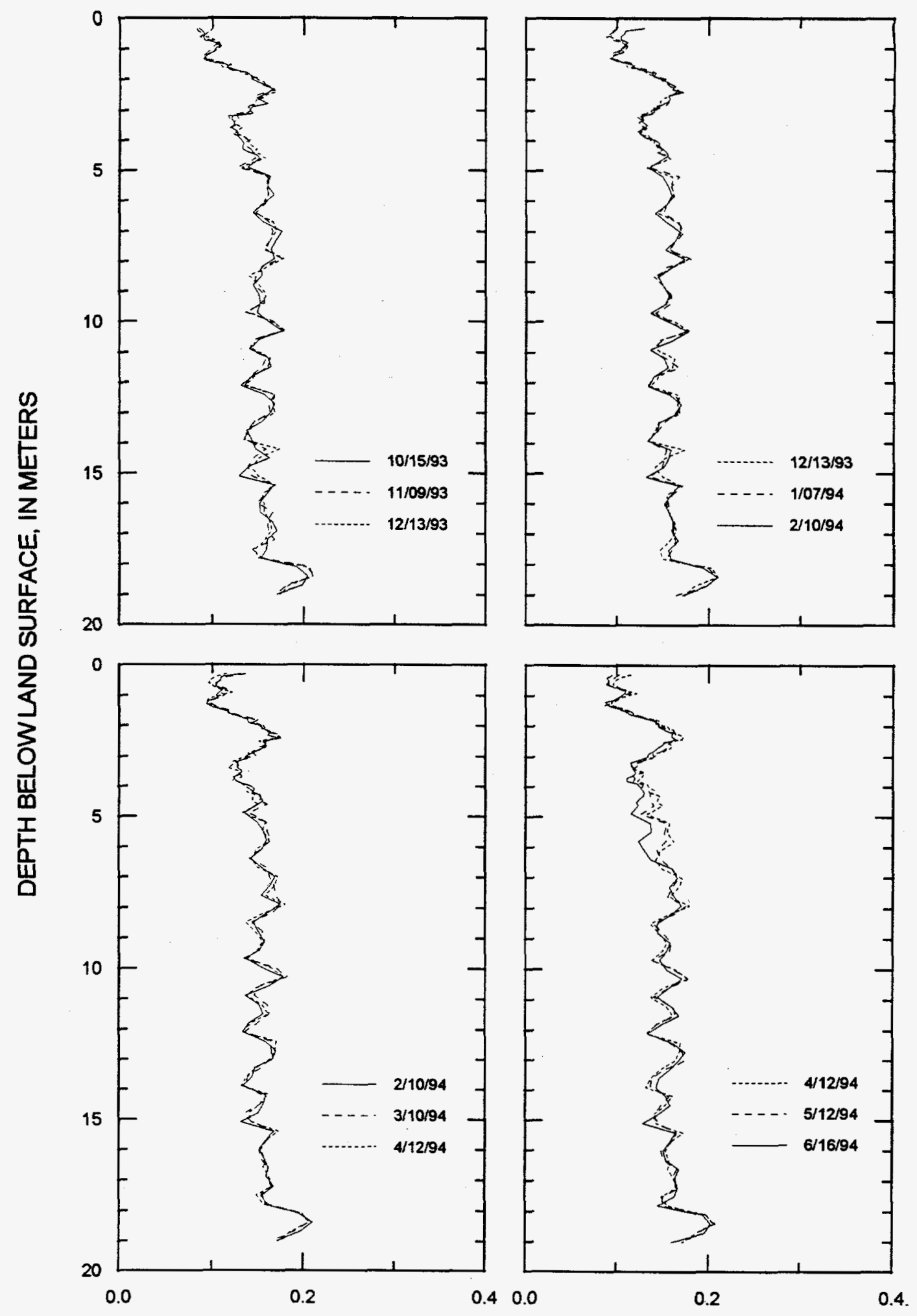

VOLUMETRIC WATER CONTENT, IN CUBIC CENTIMETER PER CUBIC CENTIMETER

Figure 7. Volumetric water-content profiles for UE-29 UZN\#92 in the Yucca Mountain area, Nevada--Continued. 

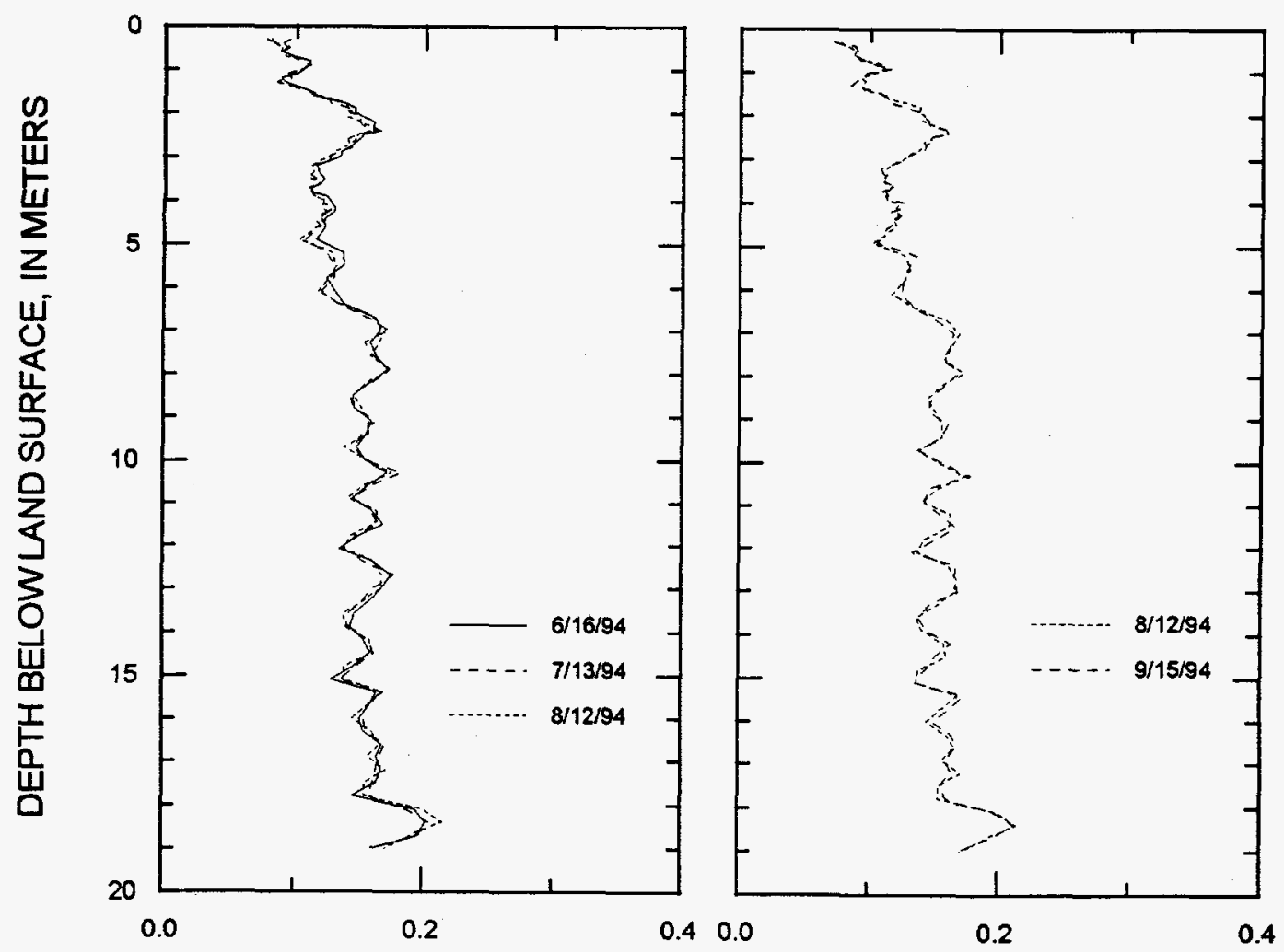

\section{VOLUMETRIC WATER CONTENT, IN CUBIC CENTIMETER PER CUBIC CENTIMETER}

Figure 7. Volumetric water-content profiles for UE-29 UZN\#92 in the Yucca Mountain area, Nevada--Continued.

of $29.11 \mathrm{~m}$ was measured. The observed range in water level was $2.70 \mathrm{~m}$ for water years $1993-94$. Water levels were in a decreasing trend from October 1, 1992, to January 11, 1993. After the January 17-19, 1993, period of streamflow, the ground-water level rose $1.99 \mathrm{~m}$ in 18 days until February 8, 1993. Water levels decreased from February 8-9, 1993. After the

February 9, 1993, streamflow, the ground-water level rose $0.69 \mathrm{~m}$ in 9 days until February 19, 1993. Water levels decreased from February 19-22, 1993. After the February 23, 1993, streamflow, the ground-water level rose $0.20 \mathrm{~m}$ in 9 days until March 3, 1993. Water levels then generally decreased until September 29, 1994.

The highest water level in UE-29 UZN\#91 was on March 10, 1993, when a depth to water of $15.49 \mathrm{~m}$ was measured. The lowest water level was on January 4-14, 1993, when a depth to water of $17.41 \mathrm{~m}$ was measured. The observed range in water level was $1.92 \mathrm{~m}$ for water years 1993-94. Water levels were in a decreasing trend from October 1, 1992, to January 14, 1993. After the January 17-19, 1993, period of streamflow, the ground-water level rose
$1.62 \mathrm{~m}$ in 25 days. Water levels decreased from February 8-10, 1993. After the February 9, 1993, streamflow, the ground-water level rose $0.29 \mathrm{~m}$ in 14 days. Water levels decreased from February 24-25, 1993. After the February 23, 1993, streamflow, the ground-water level rose $0.07 \mathrm{~m}$ in 13 days until March 10, 1993. Water levels then generally decreased until September 29, 1994.

\section{Water-Quality Data}

Three water samples were collected for analysis of chemical composition and physical properties (table 10). A bailed sample was collected from UE-29 a\#1 on February 3, 1993. Although the well was not bailed enough to empty three well-bore volumes, the 2-in.-diameter bailer was much too small for large volume bailing of the 3-ft-diameter well; the sample should represent recently recharged ground water. Water was heard dripping in the well after the January $17-19,1993$, period of streamflow. Water 
Table 7. Depth-to-water measurements in UE-29 a\#1 in the Yucca Mountain area, Nevada

[S, steel tape; E, electric tape]

\begin{tabular}{|c|c|c|c|c|c|c|c|}
\hline Date & Time & $\begin{array}{l}\text { Depth to water below } \\
\text { measuring point } \\
\text { (meters) }\end{array}$ & Method & Date & Time & $\begin{array}{l}\text { Depth to water below } \\
\text { measuring point } \\
\text { (meters) }\end{array}$ & Method \\
\hline Oct. 8, 1992 & 1306 & 27.07 & $\mathbf{s}$ & Mar. 12,1993 & 1013 & 23.96 & $\bar{E}$ \\
\hline Oct. 23, 1992 & 1115 & 27.15 & $\mathbf{s}$ & Mar. 15, 1993 & 1000 & 24.02 & E \\
\hline Oct. 26, 1992 & 1027 & 27.14 & $\mathbf{s}$ & Mar. 18, 1993 & 1410 & 24.10 & E \\
\hline Nov. 2, 1992 & 1048 & 27.15 & $s$ & Mar. 23, 1993 & 1025 & 24.25 & E \\
\hline Nov. 16,1992 & 1302 & 27.20 & $S$ & Mar. 29, 1993 & 1048 & 24.41 & E \\
\hline Nov. 30,1992 & 1135 & 27.28 & $s$ & Apr. 5, 1993 & 1518 & 24.56 & E \\
\hline Dec. 9, 1992 & 1153 & 27.27 & $\mathbf{S}$ & Apr. 14,1993 & 1217 & 24.76 & E \\
\hline Dec. 14, 1992 & 1031 & 27.28 & $\mathbf{S}$ & Apr. 23,1993 & 1038 & 24.88 & E \\
\hline Dec. 22, 1992 & 1139 & 27.29 & $\mathrm{~s}$ & May 3, 1993 & 1440 & 24.99 & E \\
\hline Dec. 29, 1992 & 1123 & 27.24 & $S$ & May 17, 1993 & 1135 & 25.19 & E \\
\hline Jan. 4, 1993 & 1415 & 27.28 & $S$ & June 1, 1993 & 1106 & 25.33 & E \\
\hline Jan. 11, 1993 & 1140 & 27.30 & $s$ & June 7, 1993 & 1009 & 25.38 & E \\
\hline Jan. 14, 1993 & 1120 & 27.29 & $\mathbf{S}$ & June 14, 1993 & 1637 & 25.42 & $\mathbf{E}$ \\
\hline Jan. 19, 1993 & 1154 & 26.56 & $\mathbf{E}$ & June 29, 1993 & 0910 & 25.48 & $\mathbf{E}$ \\
\hline Jan. 20, 1993 & 1302 & 25.79 & $\mathbf{S}$ & July 13, 1993 & 1311 & 25.61 & E \\
\hline Jan. 21, 1993 & 1121 & 25.12 & $\mathbf{s}$ & Aug. 10, 1993 & 1351 & 25.91 & E \\
\hline Jan. 22, 1993 & 1030 & 24.65 & $\mathrm{~s}$ & Aug. 26, 1993 & 1510 & 26.05 & $\mathbf{s}$ \\
\hline Jan. 23, 1993 & 1355 & 24.46 & $s$ & Sep. 9, 1993 & 1356 & 26.11 & E \\
\hline Jan. 24, 1993 & 0911 & 24.38 & $\mathbf{S}$ & Oct. 15,1993 & 1113 & 26.21 & $\mathbf{s}$ \\
\hline Jan. 25, 1993 & 1122 & 24.37 & $S$ & Nov. 9, 1993 & 1154 & 26.34 & $\mathbf{S}$ \\
\hline Jan. 26, 1993 & 1221 & 24.35 & $\mathbf{E}$ & Nov. 15,1993 & 0937 & 26.37 & $\mathbf{S}$ \\
\hline Jan. 27, 1993 & 1430 & 24.35 & E & Nov. 22, 1993 & 1027 & 26.32 & $\mathbf{S}$ \\
\hline Jan. 28, 1993 & 1110 & 24.38 & $\mathbf{E}$ & Dec. 2, 1993 & 0951 & 26.41 & $\mathbf{S}$ \\
\hline Jan. 29, 1993 & 1605 & 24.42 & E & Dec. 13, 1993 & 1116 & 26.43 & $\mathbf{s}$ \\
\hline Jan. 30, 1993 & 0850 & 24.43 & $\mathbf{E}$ & Dec. 16, 1993 & 1359 & 26.43 & $\mathbf{S}$ \\
\hline Feb. 1, 1993 & 1106 & 24.50 & E & Jan. 7, 1994 & 1145 & 26.48 & $\mathbf{s}$ \\
\hline Feb. 3, 1993 & 1037 & 24.55 & E & Jan. 21, 1994 & 0924 & 26.52 & $\mathbf{s}$ \\
\hline Feb. 5, 1993 & 1510 & 24.60 & $\mathbf{E}$ & Jan. 27, 1994 & 1408 & 26.51 & $\mathbf{S}$ \\
\hline Feb. 8, 1993 & 1100 & 24.62 & $\mathbf{E}$ & Feb. 4, 1994 & 1235 & 26.50 & $\mathbf{s}$ \\
\hline Feb. 9, 1993 & 1409 & 24.68 & $\mathrm{E}$ & Feb. 10, 1994 & 1202 & 26.51 & $\mathbf{S}$ \\
\hline Feb. 10, 1993 & 1040 & 24.64 & E & Feb. 28, 1994 & 1416 & 26.59 & $\mathbf{S}$ \\
\hline Feb. 11, 1993 & 1010 & 24.13 & E & Mar. 10, 1994 & 1122 & 26.65 & $\mathbf{S}$ \\
\hline Feb. 12, 1993 & 1128 & 23.66 & $\mathbf{E}$ & Mar. 21, 1994 & 1047 & 26.69 & $\mathbf{S}$ \\
\hline Feb. 14, 1993 & 1200 & 23.41 & E & Mar. 30, 1994 & 0940 & 26.70 & $\mathbf{S}$ \\
\hline Feb. 16, 1993 & 1407 & 23.51 & $\mathbf{E}$ & Apr. 12, 1994 & 1206 & 26.73 & $\mathbf{S}$ \\
\hline Feb. 18, 1993 & 1025 & 23.63 & $\mathbf{E}$ & Apr. 28, 1994 & 1050 & 26.68 & $\mathbf{s}$ \\
\hline Feb. 19, 1993 & 1315 & 23.62 & E & Apr. 29, 1994 & 0947 & 26.69 & $\mathbf{S}$ \\
\hline Feb. 22, 1993 & 1057 & 23.83 & E & May 12, 1994 & 1125 & 26.68 & $\mathbf{S}$ \\
\hline Feb. 24, 1993 & 1116 & 23.84 & E & May 20, 1994 & 0932 & 26.74 & $\mathbf{S}$ \\
\hline Feb. 25,1993 & 1000 & 23.89 & $\mathbf{E}$ & June 1, 1994 & 1416 & 26.75 & $S$ \\
\hline Feb. 26, 1993 & 1100 & 23.87 & $\mathbf{E}$ & June 16, 1994 & 1009 & 26.69 & $S$ \\
\hline Mar. 1, 1993 & 1051 & 23.86 & $\mathrm{E}$ & July 13, 1994 & 1015 & 26.72 & $\mathbf{S}$ \\
\hline Mar. 3, 1993 & 1400 & 23.83 & $\mathrm{E}$ & July 25,1994 & 1050 & 26.80 & $\mathbf{s}$ \\
\hline Mar. 5, 1993 & 1051 & 23.88 & E & Aug. 12, 1994 & 1021 & 26.84 & $\mathbf{s}$ \\
\hline Mar. 8, 1993 & 1121 & 23.87 & E & Sep. 15, 1994 & 1023 & 26.93 & $S$ \\
\hline Mar. 10, 1993 & 1033 & 23.88 & E & Sep. 29,1994 & 1320 & 26.91 & $\mathrm{~s}$ \\
\hline
\end{tabular}


Table 8. Depth-to-water measurements in UE-29 a\#2 in the Yucca Mountain area, Nevada

[S, steel tape; E, electric tape]

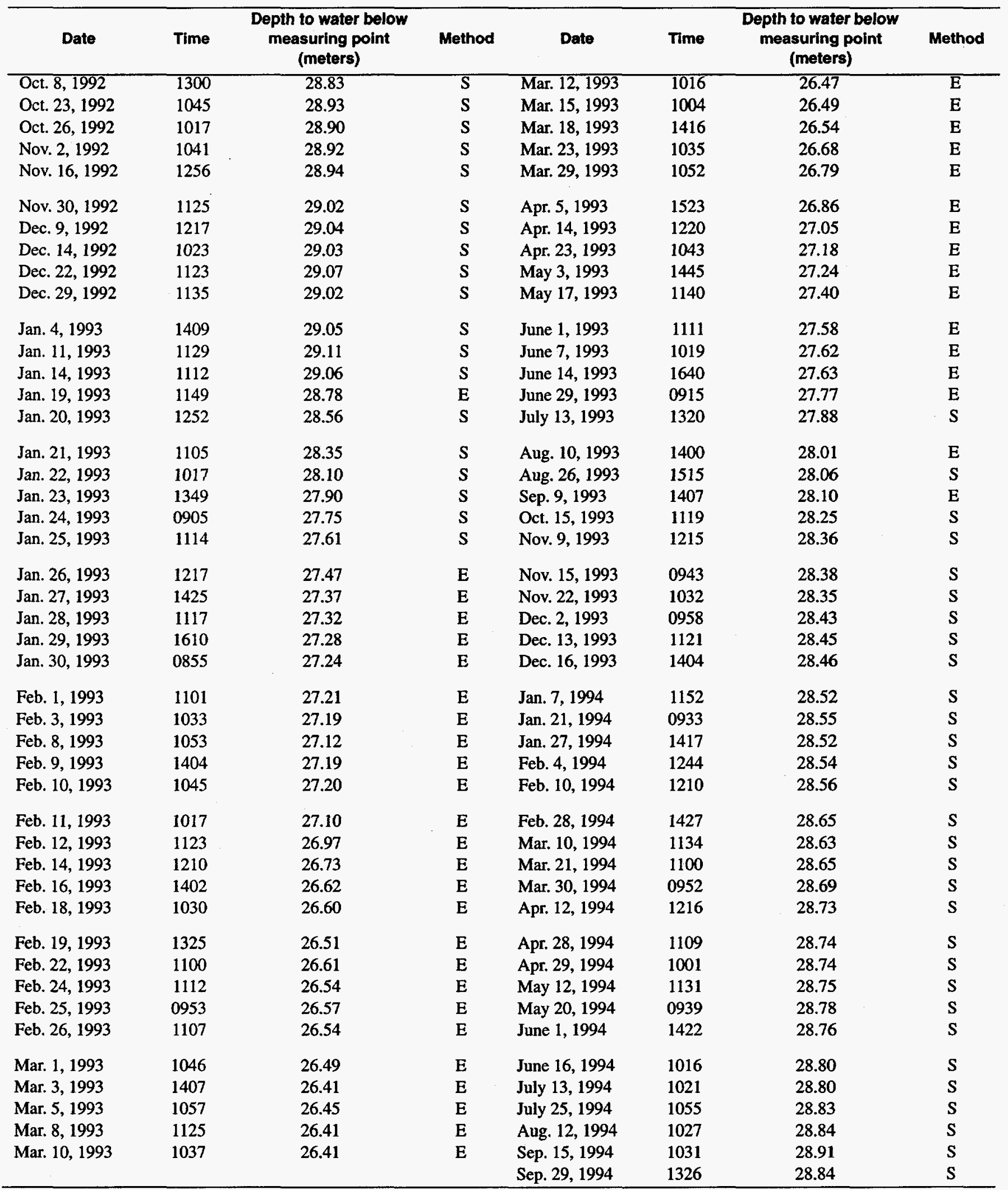


Table 9. Depth-to-water measurements in UE-29 UZN\#91 in the Yucca Mountain area, Nevada

[S, steel tape; E, electric tape]

\begin{tabular}{|c|c|c|c|c|c|c|c|}
\hline Date & Time & $\begin{array}{l}\text { Depth to water below } \\
\text { measuring point } \\
\text { (meters) }\end{array}$ & Method & Date & Time & $\begin{array}{l}\text { Depth to water below } \\
\text { measuring point } \\
\text { (meters) }\end{array}$ & Method \\
\hline Oct. 8, 1992 & 1144 & 17.25 & $\mathbf{S}$ & Mar. 12, 1993 & 1005 & 15.51 & $\mathbf{S}$ \\
\hline Oct. 23, 1992 & 1025 & 17.29 & $\mathbf{s}$ & Mar. 15, 1993 & 0953 & 15.51 & $\mathrm{~s}$ \\
\hline Oct. 26, 1992 & 1008 & 17.29 & $\mathbf{s}$ & Mar. 18, 1993 & 1350 & 15.52 & $\mathbf{s}$ \\
\hline Nov. 2, 1992 & 1029 & 17.30 & $\mathbf{S}$ & Mar. 23, 1993 & 1007 & 15.57 & $\mathbf{S}$ \\
\hline Nov. 16,1992 & 1145 & 17.33 & $\mathbf{S}$ & Mar. 29, 1993 & 1043 & 15.63 & $S$ \\
\hline Nov. 30, 1992 & 1100 & 17.37 & $S$ & Apr. 5, 1993 & 1340 & 15.69 & $s$ \\
\hline Dec. 9, 1992 & 1135 & 17.38 & $\mathbf{S}$ & Apr. 14,1993 & 1200 & 15.79 & E \\
\hline Dec. 14,1992 & 1009 & 17.37 & $\mathbf{s}$ & Apr. 23, 1993 & 1027 & 15.87 & $\mathrm{~s}$ \\
\hline Dec. 22, 1992 & 1055 & 17.39 & $\mathbf{S}$ & May 3, 1993 & 1322 & 15.94 & $\mathbf{S}$ \\
\hline Dec. 29, 1992 & 1037 & 17.39 & $S$ & May 17,1993 & 1110 & 16.05 & $s$ \\
\hline Jan. 4, 1993 & 1353 & 17.41 & $\mathbf{S}$ & June 1, 1993 & 1057 & 16.14 & $\mathbf{s}$ \\
\hline Jan. 11, 1993 & 1110 & 17.41 & $\mathbf{S}$ & June 7,1993 & 1001 & 16.17 & $\mathrm{~s}$ \\
\hline Jan. 14, 1993 & 1057 & 17.41 & $\mathbf{S}$ & June 14, 1993 & 1448 & 16.21 & $\mathbf{s}$ \\
\hline Jan. 19, 1993 & 1138 & 17.28 & $\mathbf{s}$ & June 29, 1993 & 0854 & 16.28 & $s$ \\
\hline Jan. 20, 1993 & 1238 & 17.01 & $S$ & July 13, 1993 & 1135 & 16.35 & $S$ \\
\hline Jan. 21, 1993 & 1140 & 16.75 & $S$ & Aug. 10, 1993 & 1232 & 16.47 & $S$ \\
\hline Jan. 22, 1993 & 0945 & 16.54 & $\mathbf{S}$ & Aug. 26, 1993 & 1500 & 16.54 & $\mathrm{~s}$ \\
\hline Jan. 23, 1993 & 1320 & 16.33 & $\mathbf{S}$ & Sep. 9,1993 & 1205 & 16.60 & $s$ \\
\hline Jan. 24, 1993 & 0850 & 16.23 & $\mathbf{S}$ & Oct. 15, 1993 & 1017 & 16.74 & $\mathbf{S}$ \\
\hline Jan. 25, 1993 & 1104 & 16.12 & $\mathbf{S}$ & Nov. 9, 1993 & 1032 & 16.83 & $S$ \\
\hline Jan. 26, 1993 & 1119 & 16.03 & $\mathrm{~s}$ & Nov. 15, 1993 & 0924 & 16.85 & $\mathrm{~s}$ \\
\hline Jan. 27, 1993 & 1420 & 15.97 & $\mathbf{s}$ & Nov. 22, 1993 & 1016 & 16.86 & $\mathbf{S}$ \\
\hline Jan. 28, 1993 & 1057 & 15.94 & $\mathbf{S}$ & Dec. 2, 1993 & 0942 & 16.90 & $\mathbf{S}$ \\
\hline Jan. 29, 1993 & 1400 & 15.90 & $\mathbf{s}$ & Dec. 13, 1993 & 1015 & 16.93 & $s$ \\
\hline Jan. 30, 1993 & 0828 & 15.88 & $\mathbf{S}$ & Dec. 16,1993 & 1352 & 16.94 & $s$ \\
\hline Feb. 1, 1993 & 1052 & 15.85 & $\mathbf{S}$ & Jan. 7, 1994 & 1032 & 17.00 & $\mathrm{~s}$ \\
\hline Feb. 3, 1993 & 1027 & 15.83 & $\mathbf{S}$ & Jan. 21, 1994 & 0913 & 17.03 & $s$ \\
\hline Feb. 5, 1993 & 1324 & 15.82 & $\mathbf{S}$ & Jan. 27, 1994 & 1354 & 17.03 & $\mathbf{s}$ \\
\hline Feb. 8,1993 & 1046 & 15.79 & $\mathbf{E}$ & Feb. 4, 1994 & 1217 & 17.05 & S \\
\hline Feb. 9,1993 & 1356 & 15.80 & $\mathbf{E}$ & Feb. 10, 1994 & 1056 & 17.06 & $s$ \\
\hline Feb. 10, 1993 & 1020 & 15.83 & $\mathbf{s}$ & Feb. 28, 1994 & 1401 & 17.09 & $\mathrm{~s}$ \\
\hline Feb. 11, 1993 & 0958 & 15.80 & $\mathbf{S}$ & Mar. 10, 1994 & 1014 & 17.10 & $\mathbf{s}$ \\
\hline Feb. 12, 1993 & 1057 & 15.77 & $\mathbf{S}$ & Mar. 21, 1994 & 1032 & 17.12 & $\mathbf{S}$ \\
\hline Feb. 14, 1993 & 1132 & 15.67 & $s$ & Mar. 30, 1994 & 0925 & 17.13 & $\mathbf{s}$ \\
\hline Feb. 16, 1993 & 1352 & 15.61 & $S$ & Apr. 12,1994 & 1103 & 17.15 & $s$ \\
\hline Feb. 18, 1993 & 1007 & 15.58 & $\mathbf{S}$ & Apr. 28, 1994 & 1001 & 17.17 & $\mathbf{S}$ \\
\hline Feb. 19, 1993 & 1310 & 15.56 & $\mathbf{S}$ & Apr. 29, 1994 & 0931 & 17.17 & $\mathbf{S}$ \\
\hline Feb. 22, 1993 & 1049 & 15.57 & $S$ & May 12, 1994 & 1025 & 17.18 & $\mathbf{S}$ \\
\hline Feb. 24, 1993 & 1106 & 15.54 & $\mathbf{S}$ & May 20, 1994 & 0918 & 17.19 & $\mathbf{S}$ \\
\hline Feb. 25, 1993 & 0941 & 15.56 & $\mathrm{E}$ & June 1, 1994 & 1405 & 17.20 & $\mathbf{s}$ \\
\hline Feb. 26, 1993 & 1044 & 15.55 & $s$ & June 16, 1994 & 0908 & 17.22 & $\mathbf{s}$ \\
\hline Mar. 1, 1993 & 1024 & 15.54 & $s$ & July 13, 1994 & 0916 & 17.24 & $\mathbf{s}$ \\
\hline Mar. 3, 1993 & 1239 & 15.51 & E & July 25,1994 & 1042 & 17.25 & $s$ \\
\hline Mar. 5, 1993 & 1043 & 15.51 & $S$ & Aug. 12, 1994 & 0920 & 17.26 & $S$ \\
\hline Mar. 8, 1993 & 1105 & 15.50 & $s$ & Sep. 15, 1994 & 0920 & 17.30 & $S$ \\
\hline Mar. 10, 1993 & 1026 & 15.49 & $s$ & Sep. 29, 1994 & 1309 & 17.30 & $\mathbf{s}$ \\
\hline
\end{tabular}




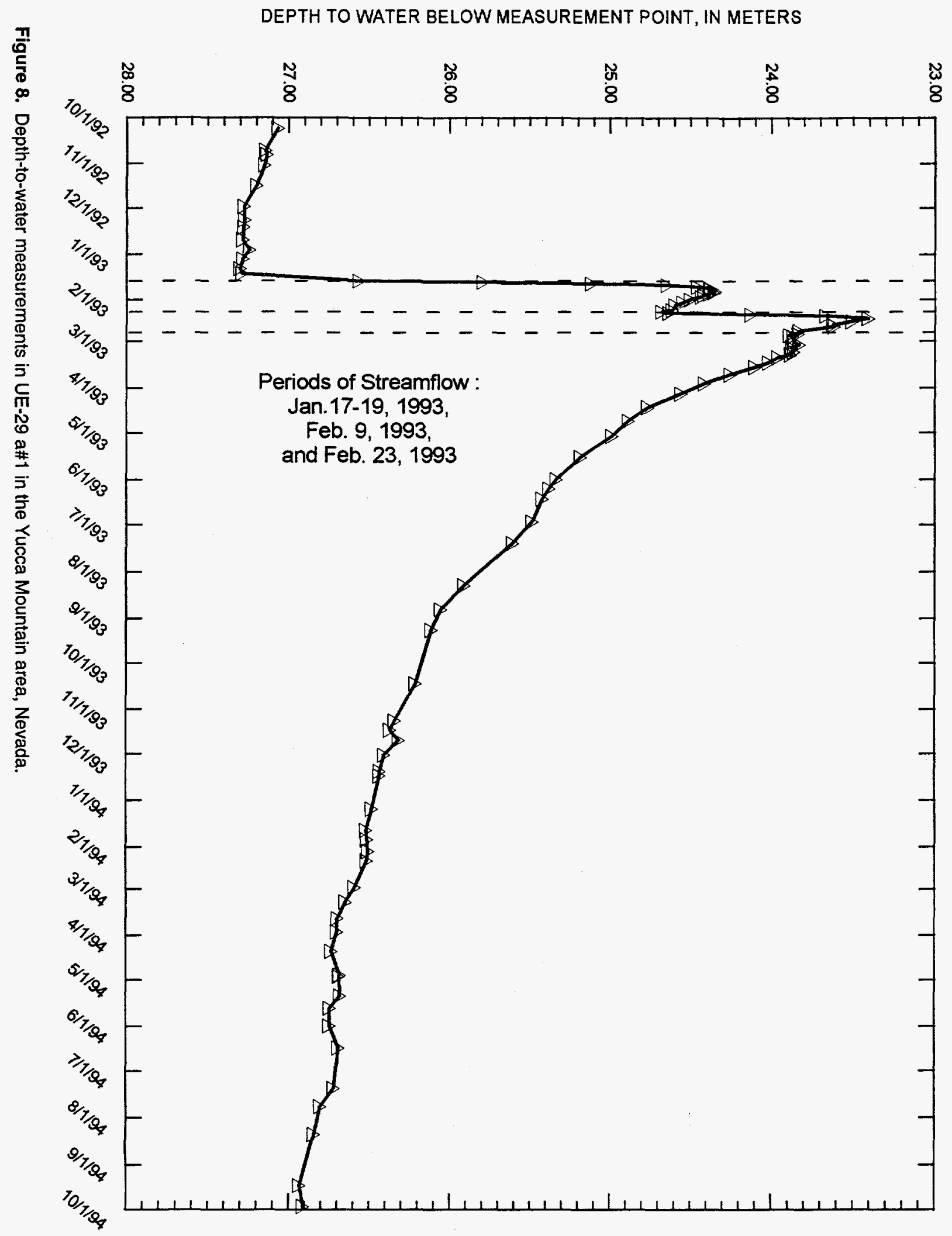




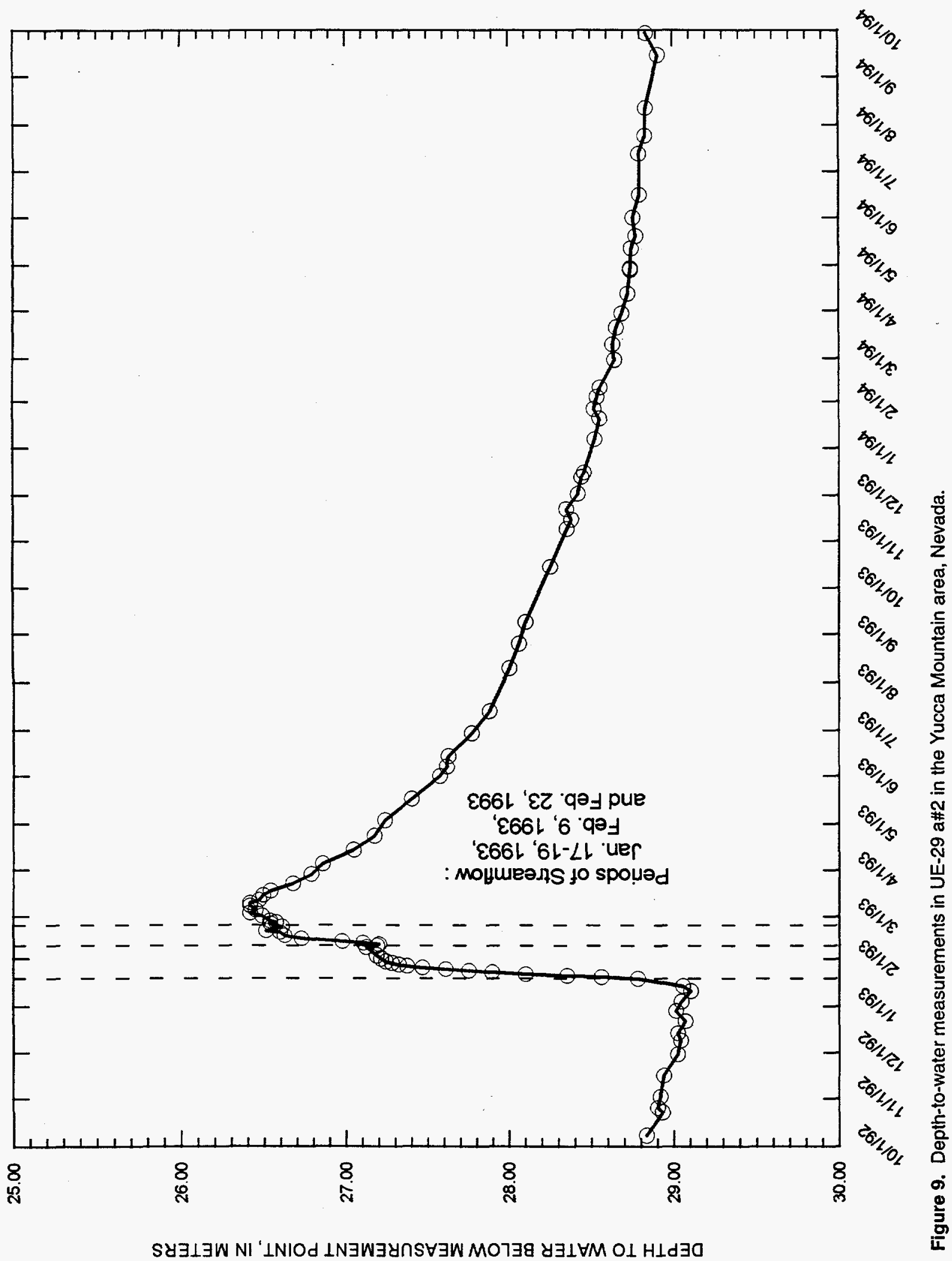




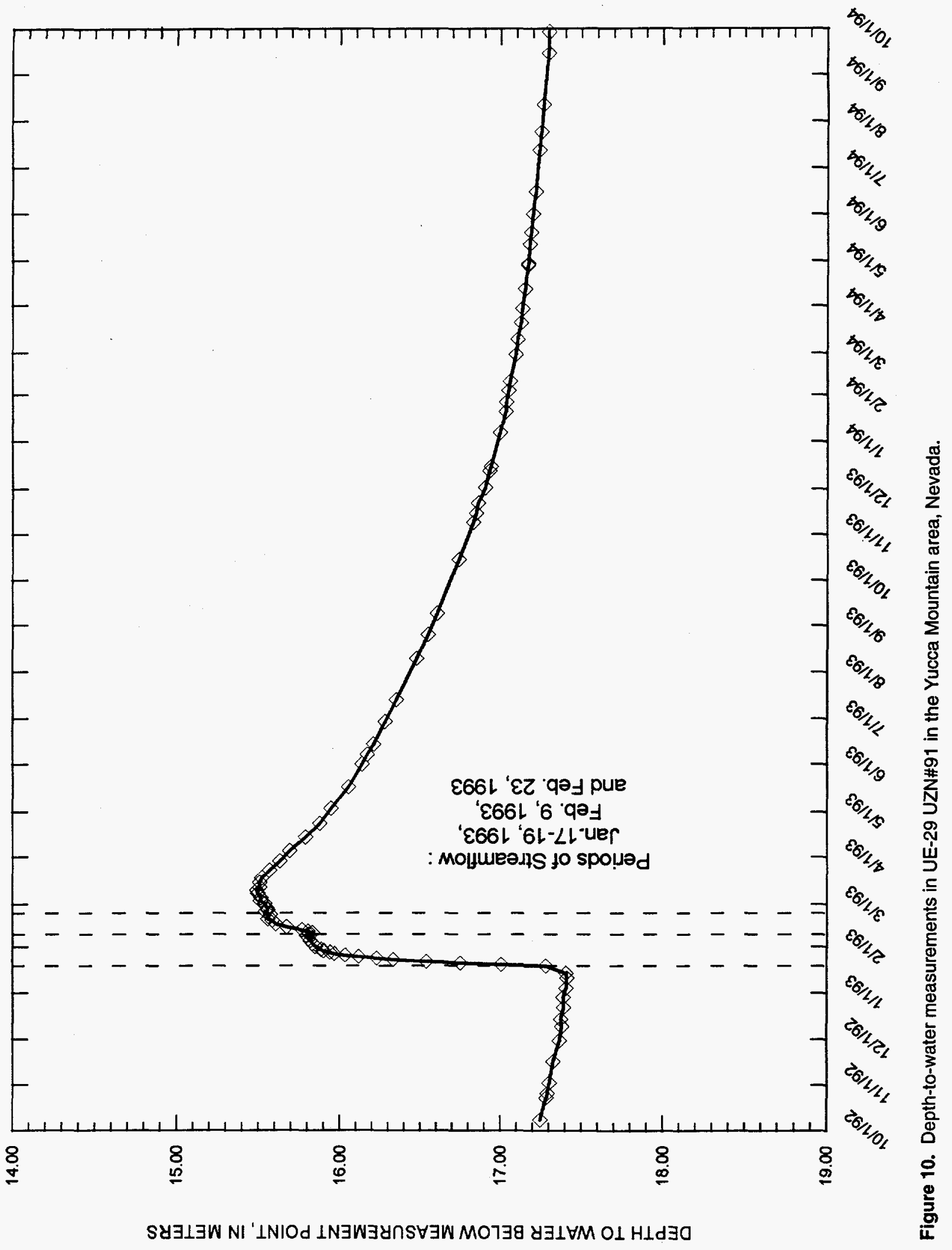


Table 10. Chemical composition of water samples obtained in the Fortymile Wash drainage basin in the Yucca Mountain area, Nevada

[Analyses by U.S. Geological Survey; $\mu \mathrm{S} / \mathrm{cm}$, microsiemens per centimeter at 25 degrees Celsius; $\mathrm{mg} / \mathrm{L}$, milligrams per liter; $\mu \mathrm{g} / \mathrm{L}$, micrograms per liter; $\mathrm{pCi} / \mathrm{L}$, picocuries per liter; \%o, parts per thousand relative to standard mean ocean water; --, no data]

\begin{tabular}{lccc}
\hline \multicolumn{1}{c}{$\begin{array}{c}\text { Constituent, property, } \\
\text { or isotope }\end{array}$} & $\begin{array}{c}\text { Bailed sample from } \\
\text { UE-29 a*1 } \\
\text { February 3, 1993 }\end{array}$ & $\begin{array}{c}\text { Dipped sample from } \\
\text { Delirium Canyon Wash } \\
\text { February 9, 1993 }\end{array}$ & $\begin{array}{c}\text { Dipped sample from } \\
\text { Pah Canyon Wash } \\
\text { February 23, 1993 }\end{array}$ \\
\hline Specific conductance $(\mu \mathrm{S} / \mathrm{cm})$ & 247 & 118 & 140 \\
$\mathrm{pH}($ units) & 6.4 & 7.8 & 8.0 \\
Calcium $(\mathrm{mg} / \mathrm{L})$ & 16 & 12 & 14 \\
Sodium $(\mathrm{mg} / \mathrm{L})$ & 36 & 7.6 & 9.3 \\
Magnesium $(\mathrm{mg} / \mathrm{L})$ & 2.3 & 2.4 & 2.6 \\
Alkalinity as HCO ${ }_{3}(\mathrm{mg} / \mathrm{L})$ & 108 & 48 & 54 \\
Sulfate $(\mathrm{mg} / \mathrm{L})$ & 7.6 & 7.8 & 10 \\
Chloride $(\mathrm{mg} / \mathrm{L})$ & 9.6 & 3.2 & 4.3 \\
Fluoride $(\mathrm{mg} / \mathrm{L})$ & 0.2 & 0.3 & 0.3 \\
Iron $(\mu \mathrm{g} / \mathrm{L})$ & 4 & 27 & 19 \\
Manganese $(\mu \mathrm{g} / \mathrm{L})$ & 1 & 2 & 1 \\
Nitrate $(\mathrm{mg} / \mathrm{L})$ & -- & -- & 2 \\
Silica $(\mathrm{mg} / \mathrm{L})$ & 54 & 33 & 34 \\
Strontium $(\mu \mathrm{g} / \mathrm{L})$ & 55 & 18 & 21 \\
Lithium $(\mu \mathrm{g} / \mathrm{L})$ & 37 & 5 & 6 \\
Bromide $(\mathrm{mg} / \mathrm{L})$ & 0.07 & -- & -- \\
Tritium $(\mathrm{pCi} / \mathrm{L})$ & 35 & 33 & 32 \\
$\delta \mathrm{D}(\% \circ)$ & -90.2 & -88.1 & -82.3 \\
$\delta^{18}(\% \circ)$ & -12.53 & -12.37 & -11.28 \\
\hline
\end{tabular}

levels in the well rose approximately $2.5 \mathrm{~m}$ after the streamflow.

The other two samples were dipped samples during periods of streamflow. One sample was dipped from Delirium Canyon tributary at the road crossing approximately $100 \mathrm{~m}$ above the confluence with Fortymile Wash on February 9, 1993. The nearly steady or slowly declining streamflow was well mixed. The other sample was dipped from Pah Canyon tributary approximately $300 \mathrm{~m}$ above the confluence with Fortymile Wash on February 23, 1993. The nearly steady or slowly declining streamflow was well mixed.

\section{SUMMARY}

From October to early December 1992, there was a small amount of precipitation in the Fortymile Wash drainage basin. No streamflow was observed, and neutron logging indicated no precipitation was infiltrating. From early Decembér 1992 until early April 1993, precipitation occurred from a series of regional storms. Streamflow occurred throughout most of the upper Fortymile Wash drainage basin during January 17-19, 1993. Localized streamflow occurred in the Pah and Delirium Canyon drainage basins of the Fortymile Wash drainage basin during February 9 and 23,1993 . The January streamflow went over two neutron-access borehole locations and infiltrated into the streambed sediments. The moisture moved into the unsaturated zone and then redistributed in the vertical profile during the remainder of January. Ground-water levels rose at wells UE-29 a\#1 and UE-29 a\#2, and neutron-access borehole UE-29 UZN\#91 after each of the three periods of streamflow for approximately 1 to 2 weeks and then declined.

For the remainder of water year 1993, from early April 1993 to September 1993, there were only small amounts of precipitation, and no streamflow was observed. The moisture in the entire vertical profiles of the two neutron-access boreholes generally decreased from February to September 1993. Ground-water levels steadily declined during this period. 
During water year 1994, there was only a small amount of precipitation during the year. The winter/spring period, December to April 1994, had the most precipitation. No streamflow was observed during water year 1994. The vertical moisture content profiles had only minor fluctuations in the upper $1 \mathrm{~m}$ during water year 1994. Ground-water levels continued their steady decline from the 1993 highs.

\section{REFERENCES CITED}

Ambos, D.S., Flint, A.L., and Hevesi, J.A., (1995), Precipitation data for water years 1992 and 1993 from a network of nonrecording gages at Yucca Mountain, Nevada: U.S. Geological Survey Open-File Report 94-146, $100 \mathrm{p}$.

Benson, L., and Klieforth, H., 1989, Stable isotopes in precipitation and ground water in the Yucca Mountain region, southern Nevada-Paleoclimate implications, in Peterson, D.H., ed., Aspects of climate variability in the Pacific and Western Americas: American Geophysical Union Geophysical Monograph 55, p. 41-59.

Blout, D.O., Hammermeister, D.P., Loskot, C.L., and Chornack, M.P., 1994, Geohydrologic data collected from shallow neutron-access boreholes and resultantpreliminary geohydrologic evaluations, Yucca Mountain area, Nye County, Nevada: U.S. Geological Survey Open-File Report 92-657, 147 p.

Boucher, M.S., 1994, Water levels in wells J-11 and J-12, 1989-91, Yucca Mountain area, Nevada: U.S. Geological Survey Open-File Report 94-303, 9 p.

Claassen, H.C., 1985, Sources and mechanisms of recharge for ground water in the West-Central Amargosa Desert, Nevada-A geochemical interpretation: U.S. Geological Survey Professional Paper 712-F, 31 p.

Czarnecki, J.B., and Waddell, R.K., 1984, Finite-element simulation of ground-water flow in the vicinity of Yucca Mountain, Nevada-California: U.S. Geological Survey Water-Resources Investigations Report 84-4349, 38 p.

Emett, D.C., Hutchinson, D.D., Jonson, N.A., and O'Hair, K.L., 1994, Water resources data, Nevada, water year 1993: U.S. Geological Survey Water-Data Report NV-93-1, $596 \mathrm{p}$.

Gardner, W.H., 1986, Water content, in Klute, Amold, ed., Methods of soil analysis, part 1, Physical and mineralogical methods, (2d ed.): Agronomy Monograph no. 9 p. 493-544.

Gemmel, J.M., 1990, Water levels in periodically measured wells in the Yucca Mountain area, Nevada, 1988:

U.S. Geological Survey Open-File Report 90-113, 47 p.
Hale, G.S., and Westenburg, C.L., 1995, Selected groundwater data for Yucca Mountain region, southern Nevada and eastern California, calendar year 1993: U.S. Geological Survey Open-File Report 95-158, 67 p.

Huber, N.K., 1988, Late Cenozoic evolution of the upper Amargosa River drainage system, southwestern Great Basin, Nevada and California: U.S. Geological Survey Open-File Report 87-617, 26 p.

Kane, T.G., III, Bauer, D.J., and Martinez, C.M., 1994, Streamflow and selected precipitation data for Yucca Mountain region, southern Nevada and eastern California, water years 1986-90: U.S. Geological Survey Open-File Report 94-312, 118 p.

La Camera, R.J., and Westenburg, C.L., 1994, Selected ground-water data for Yucca Mountain region, southern Nevada and eastern California, through December 1992: U.S. Geological Survey Open-File Report 94-54, $161 \mathrm{p}$.

Luckey, R.R., Lobmeyer, D.H., and Burkhardt, D.J., 1993, Water levels in continuously monitored wells in the Yucca Mountain area, Nevada, 1985-88: U.S. Geological Survey Open-File Report 91-493, 252 p.

Moore, J.E., 1961, Records of wells, test holes, and springs in the Nevada Test Site and surrounding area: U.S. Geological Survey Open-File Report TEI-781, 22 p.

Moore, J.E., 1962, Selected logs and drilling records of wells and test holes drilled at the Nevada Test Site prior to 1960: U.S. Geological Survey Open-File Report TEI-804, $54 \mathrm{p}$.

O'Brien, G.M., 1991, Water levels in periodically measured wells in the Yucca Mountain area, Nevada, 1989: U.S. Geological Survey Open-File Report 91-178, 51 p.

O'Brien, G.M., Tucci, Patrick, Burkhardt, D.J., 1995, Water levels in the Yucca Mountain area, Nevada, 1992: U.S. Geological Survey Open-File Report 94-311, 74 p.

Osterkamp, W.R., Lane, L.J., and Savard, C.S., 1994, Recharge estimates using a geomorphic/distributedparameter simulation approach, Amargosa River basin: Water Resources Bulletin, v. 30, no. 3, p. 493-507.

Pabst, M.E., Beck, D.A., Glancy, P.A., and Johnson, J.A., 1993, Streamflow and selected precipitation data for Yucca Mountain and vicinity, Nye County, Nevada, water years 1983-85: U.S. Geological Survey OpenFile Report 93-438, 66 p.

Robison, J.H., 1984, Ground-water level data and preliminary potentiometric-surface maps, Yucca Mountain and vicinity, Nye County, Nevada: U.S. Geological Survey Water-Resources Investigations Report 84-4197, 8 p.

Robison, J.H., Stephens, D.M., Luckey, R.R., and Baldwin, D.A., 1988, Water levels in periodically measured wells in the Yucca Mountain area, Nevada, 1981-87: U.S. Geological Survey Open-File Report 88-468, 132 p. 
Savard, C.S., 1994, Ground-water recharge Fortymile Wash near Yucca Mountain, Nevada, 1992-93, in High Level Radioactive Waste Management Proceedings of the Fifth Annual International Conference, Las Vegas, Nevada, 1994: American Nuclear Society and American Society of Civil Engineers, p. 1805-1813.

1995, Selected hydrologic data from Fortymile Wash in the Yucca Mountain area, Nevada, water year 1992: U.S. Geological Survey Open-File Report 94-317, 38 p.

Squires, R.R., and Young, R.L., 1984, Flood potential of Fortymile Wash and its principle southwestern tributaries, Nevada Test Site, southern Nevada: U.S. Geological Survey Water-Resources Investigations Report 83-4001, 33 p.

Thordarson, William, Young, R.A., and Winograd, I.J., 1967, Records of wells and test holes in the Nevada Test Site and vicinity: U.S. Geological Survey Open-File Report TEI-872, 26 p.

U.S. Department of Energy, 1988, Site characterization plan, Yucca Mountain site, Nevada research and development area, Nevada: U.S. Department of Energy Report DOE RW/0199, 8 v., variously paged.
Waddell, R.K., 1982, Two-dimensional, steady-state model of ground-water flow, Nevada Test Site and vicinity, Nevada-California: U.S. Geological Survey WaterResources Investigations Report 82-4085, 72 p. 1984, Hydrologic and drill-hole data for test wells UE-29a\#1 and UE-29a\#2, Fortymile Canyon, Nevada Test Site: U.S. Geological Survey Open-File Report 84-142, 25 p.

Waddell, R.K., Robison, J.H., and Blankennagel, R.K., 1984, Hydrology of Yucca Mountain and vicinity, Nevada-California-Investigative results through mid1983: U.S. Geological Survey Water-Resources Investigations Report 84-4267, 72 p.

White, A.F., and Chuma, N.J., 1987, Carbon and isotopic mass balance models of Oasis Valley-Fortymile Canyon groundwater basin, southern Nevada: Water Resources Research, v. 23, no. 4, p. 571-582.

Winograd, I.J., and Thordarson, William, 1975, Hydrogeologic and hydrochemical framework, south-central Great Basin, Nevada-California, with special reference to the Nevada Test Site: U.S. Geological Survey Professional Paper 712-C, $126 \mathrm{p}$.

Young, R.A., 1972, Water supply for the nuclear rocket development station at the U.S. Atomic Energy Commission's Nevada Test Site: U.S. Geological Survey Water-Supply Paper 1938, 19 p. 